Portland State University

PDXScholar

\title{
Foreign Student Enrollment Planning in Five Oregon Institutions with English as a Second Language Programs
}

Maureen Denise Sprague

Portland State University

Follow this and additional works at: https://pdxscholar.library.pdx.edu/open_access_etds

Part of the Bilingual, Multilingual, and Multicultural Education Commons Let us know how access to this document benefits you.

Recommended Citation

Sprague, Maureen Denise, "Foreign Student Enrollment Planning in Five Oregon Institutions with English as a Second Language Programs" (1992). Dissertations and Theses. Paper 4562.

https://doi.org/10.15760/etd.6421

This Thesis is brought to you for free and open access. It has been accepted for inclusion in Dissertations and Theses by an authorized administrator of PDXScholar. Please contact us if we can make this document more accessible: pdxscholar@pdx.edu. 
AN ABSTRACT OF THE THESIS OF Maureen Denise Sprague for the Master of Arts in TESOL presented February 19, 1992.

Title: Foreign Student Enrollment Planning in Five Oregon Institutions With English as a Second Language Programs.

APPROVED BY THE MEMBERS OF THE THESIS COMMITTEE:

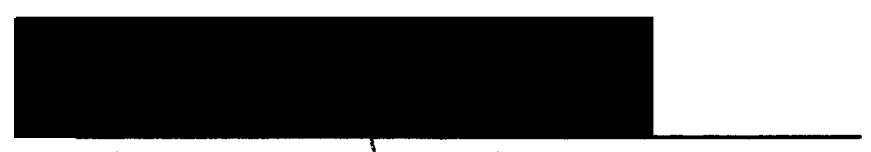

Kimberley Brown, Chair
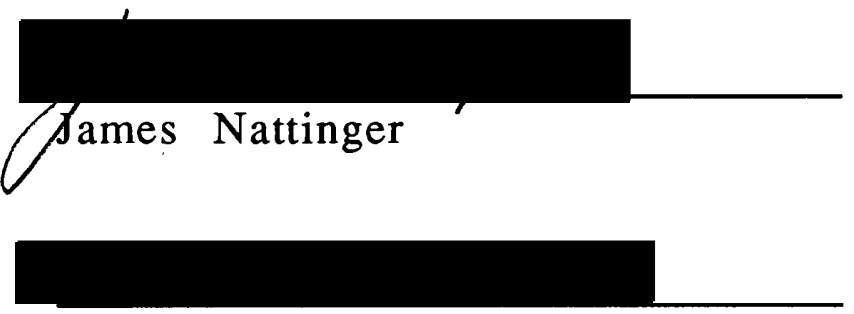

Marjorie Terdal

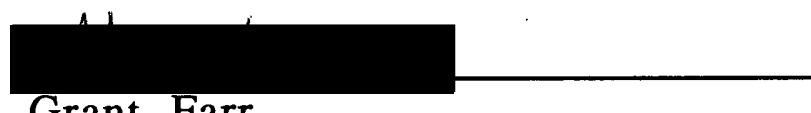

Planning for foreign students in institutions of higher education takes many forms. This study set out to find out how this planning takes place within and between three particular units in 
five universities and colleges in Oregon. The three units chosen as the focus of this study work closely with foreign students in the initial admissions process, in the orientation, visa status and services area of their stay, and thirdly in academic coursework in English as a second language programs. The titles of the units are, the admissions office, the international student services office and the English as a second language program.

This is a descriptive study and as such employed an interview format to gather current data on this topic. Interviews were held with the officers in charge of the each of the three units at each of the five institutions. The objective of the interviews was to find out the nature of planning for foreign students in each unit as well as the extent of coordination between units in planning for the enrollment of foreign students.

The literature on planning for foreign students in institutions of higher education suggests that although the numbers of foreign students attending institutions in the U.S. continue to increase, there is not an indication of institutions setting policy for foreign students. In addition, planning for foreign student enrollment has not been an integral part of the admissions office planning framework, as formal enrollment planning for domestic students is still in the early stages.

The results of this study reflect some consistency between the literature and the state of enrollment planning in the five institutions participating in this study. The nature of planning for foreign students in the admissions unit, the international student 
services unit, and the English as a second language program unit are distinctively characteristic of the individual programs and also of the university or college with which the units are affiliated. 
FOREIGN STUDENT ENROLLMENT PLANNING IN FIVE OREGON INSTITUTIONS WITH ENGLISH AS A SECOND LANGUAGE PROGRAMS

b y

MAUREEN DENISE SPRAGUE

A thesis in partial fulfillment of the requirements for the degree of

MASTER OF ARTS

in

TESOL

Portland State University

1992 
TO THE OFFICE OF GRADUATE STUDIES:

The members of the Committee approve the thesis of Maureen

Denise Sprague presented February 19, 1992.

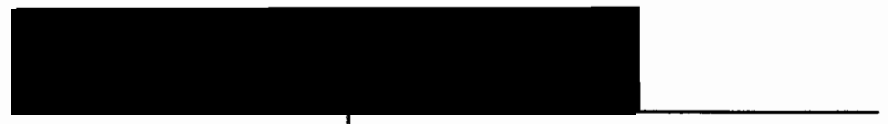

Kimberley Brown, Chair
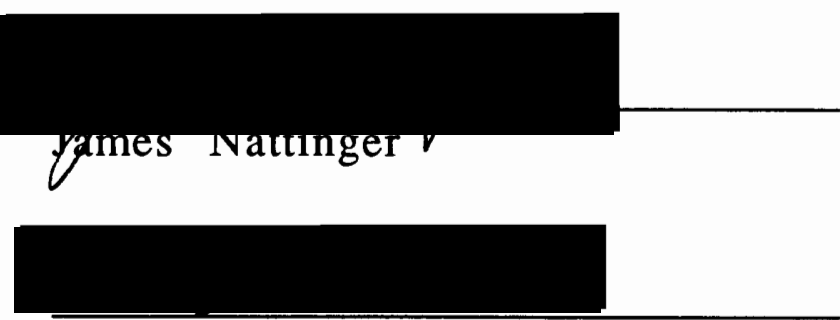

Marjorie Terdal

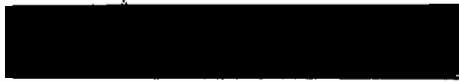

Grant Farr

APPROVED:

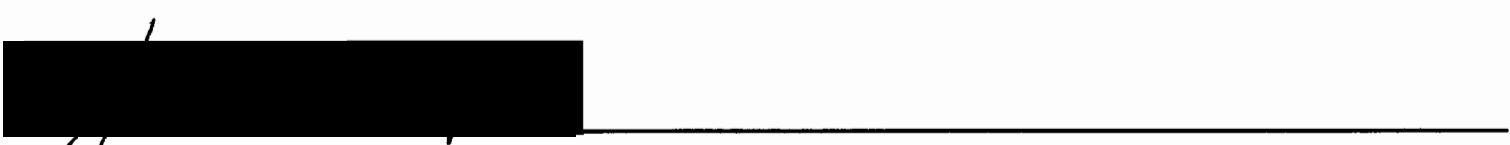

fames Nattinger, Chair, Department of Applied Linguistics

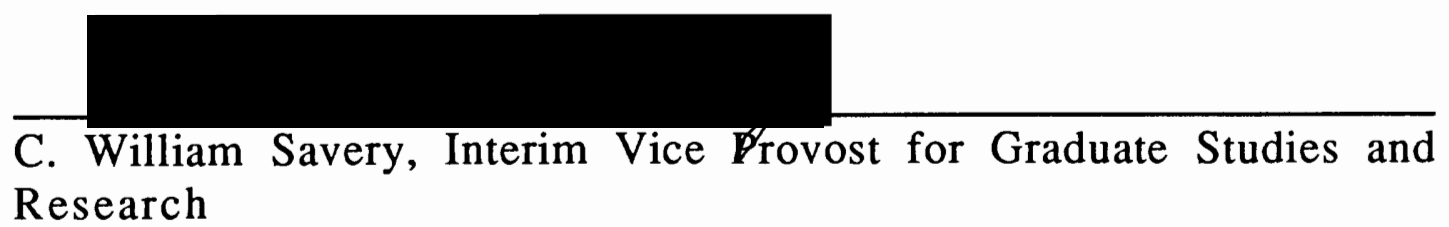




\section{TABLE OF CONTENTS}

PAGE

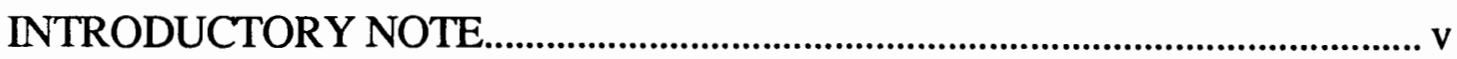

\section{CHAPTER}

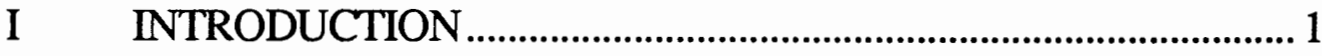

Statement of the Research Problem........................ 6

Review of the Literature............................................ 7

Enrollment Management................................. 8

Migration Patterns of Foreign Students ....14 Policy on Foreign Students and Their Admission...............................................................16

ESL Program Enrollment Planning...............2 0

I I METHODOLOGY .....................................................................2 3

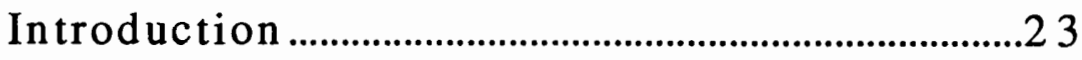

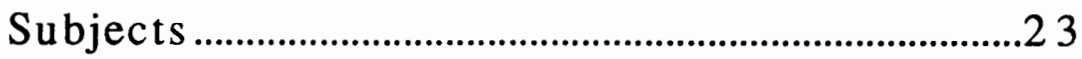

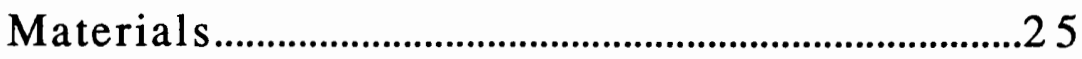

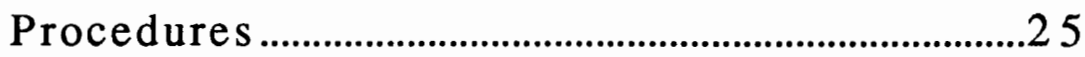

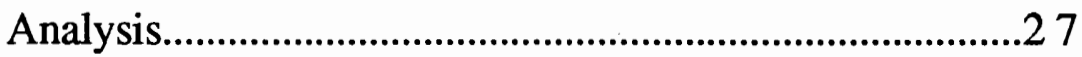

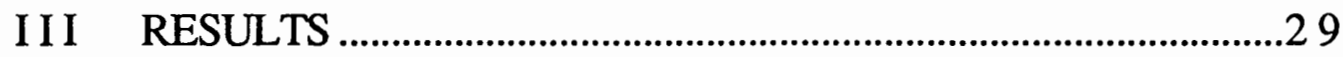

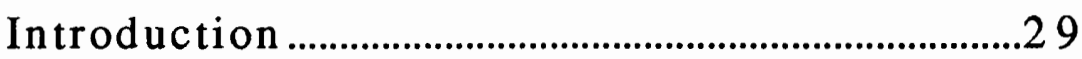


Interviews with Admissions Directors .29

Interviews with International Student Services Officers.

Interviews with English as a Second Language Program Directors........................................................5 6

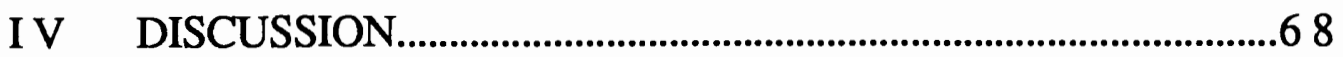
V SUMMARY, CONCLUSIONS, AND RECOMMENDATIONS. 81 Introduction .81

Summary of the Study................................................. 81

Conclusions: Admissions Directors.........................8 3

Conclusions: International Student Services Officers.

Conclusions: English as a Second Language Program Directors..........................................................8 8

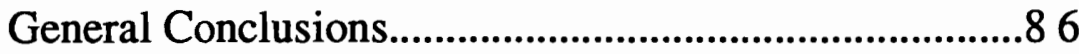

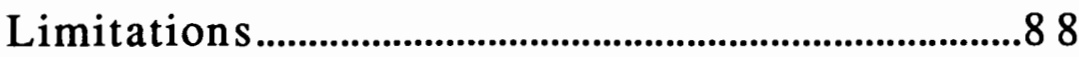

Recommendations for Further Action.....................8 9

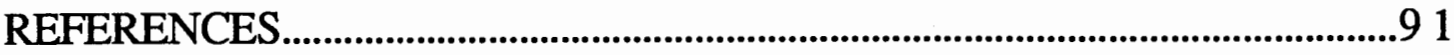

APPENDICES

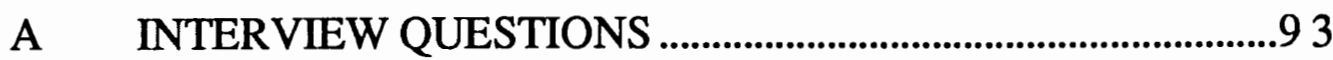

B OREGON ENROLLMENT STATISTICS ....................................97 


\section{INTRODUCTORY NOTE}

This study is concerned with students from other countries, that is, non-U.S. citizens who come to study in institutions of higher education in the United States. In the past, these students were legally referred to as "aliens." Because this word carries negative connotations, it is deemed inappropriate to use in reference to students holding citizenship other than that of the U.S. For a long time, the word "foreign" has been used for this group of students; however, in recent times, this word has also begun to suggest a negative meaning. In reaction to the negative connotations of "foreign," a new term began to be employed in reference to students from other countries. The new term, "international students," is at present a very well accepted term among the majority of individuals who work with students from other countries as well as the students themselves.

However, the term, "international students," does not only refer to non-U.S. citizens studying in the United States, it can also refer to U.S. students. When U.S. students study abroad, U.S. institutions also refer to them as "international students," because they are in fact students studying internationally.

For the purposes of this study, I had to make a choice between the term "foreign student" and the term "international student." For clarity and consistency, I chose the term "foreign 
student" to use in this study. By using the term, "foreign student," the reader will not misinterpret the meaning to include U.S.

students who study abroad. In addition, because most of the literature related to this study employs the term "foreign student," it will aid in consistency to follow this pattern.

The choice to use the term "foreign student" to refer to a nonU.S. citizen studying in the United States in no way reflects, on the part of the researcher, any negative connotations that may be associated with this word. 


\section{CHAPTER I}

\section{INTRODUCTION}

Foreign students have been coming to the United States to study for the past 200 years and their numbers are continuing to increase. Foreign students have special needs characteristic of living and studying outside of their homelands and one of their special needs is mastering a level of English to allow them to enter academic programs in colleges and universities. Many of the students who come to the U.S. do not have the required English language proficiency to study alongside American students in regular university or college courses. These students engage in English language training ranging from individual tutorials to classes in English as a second language programs or institutes.

Students from other countries follow a long and complex process in order to be admitted to an institution of higher education, including a language institute. This process involves many offices and units on a university or college campus. The units involved may include any or all of the following: the admissions office, the financial aid office, the registrar, the business office, the housing office, the English as a second language program, and the international student services office. In addition, if they are seeking 
graduate admission, individual academic departments may be involved.

Domestic students may go through a similar progression of channels, such as the application procedure, application for financial aid, evaluation of high school transcripts, and so on. However, for foreign students, the complexity is much greater than for domestic students. This has to do with the evaluation of foreign student transcripts, adherence to immigration regulations and the like, but this is not within the scope of this study. In brief, the foreign student and domestic student proceed through similar steps, but those of the foreign student are more complex and challenging (Cieslak 1955; American Council on Education 1982).

Despite the special nature of foreign student admissions, planning for foreign students on campus is directly related to the general planning for domestic students on campus. Because foreign student admissions is a sub-set of general admissions, it does not always receive the same attention as the general effort. If the domestic planning effort is not receiving adequate attention, then it follows that foreign student planning would very likely receive even less attention.

Planning for students in institutions of higher education has become known under the term "enrollment management." According to Hossler (Hossler \& Bean 1990), this came about in the early 1980s, when as a result of declining enrollments, practitioners became concerned about marketing and retention. Realizing that these two areas had not been previously linked, these two functions 
were joined under the term "enrollment management." This term refers to "institutional efforts to influence the characteristics and the size of the enrolled student bodies" (p. xiii) by coordinating the efforts of various units such as admissions, financial aid, retention, and a number of other student affairs areas.

Enrollment planning for foreign students is different from enrollment planning for domestic students in many ways. Two of those ways which are particularly relevant to this study are the following. The first concerns the distinctive nature of world stability, both economic and political. Both areas are subject to fluctuations and change which in turn cause changes in the size and make-up of the foreign student body in institutions of higher education. Because enrollment management aims to influence both size and make-up and those characteristics of foreign student populations are subject to many changes, managing foreign student enrollment can be more difficult to control than domestic student enrollment. The second is the fact that foreign students have special needs comprising and surpassing those of domestic students. On the one hand, they have similar concerns as domestic students with respect to course selection, adjustment to a university environment and so on, but on the other hand, they have special needs characteristic of individuals studying in a foreign country, including cultural adjustment.

If enrollment planning for foreign students does not take into account that foreign students have needs including and surpassing those of domestic students, the special needs of foreign students 
may not be met. If these needs are not met due to lack of attention on the part of the planners, the foreign students will likely suffer a negative experience during their university stay.

If an institution has established its own goals and principles regarding the enrollment and support services for foreign students, it will be able to self assess to determine whether it is living up to its principles and thereby making every attempt to satisfy the foreign students' needs. In other words, making institutional goals and principles explicit regarding foreign students will establish for that institution the guidelines by which to measure its stated commitment to foreign students studying at that school.

In setting a policy, an institution decides what its purpose is in welcoming foreign students into its student body, in that a policy allows an institution to explore the motivations and reasons for having a foreign student population. Furthermore, it enables units within the institution to work from the same set of principles, which only helps to enhance cooperation and mutual support common among those working toward the same goal. In addition, determining a policy allows an institution to decide what its institutional capabilities are in relation to enrolling foreign students.

If an institution has no policy regarding foreign students, it will be even more difficult for that institution to conclude whether it is meeting the needs of those students on its campus. An absence of a stated commitment to foreign students may result in this group being overlooked in the implementation of planning decisions. 
With this special element of enrolling foreign students - that is, the need for special planning - this research begins to explore and document the status of enrollment planning for this group of students in our colleges and universities, including English as a second language programs on campuses of higher education in Oregon.

The purpose of this study is to gather information on current planning practices for foreign students at institutions of higher education in Oregon in order to develop an overview of the current state of institutional commitment to enrolling foreign students in Oregon institutions. The original objective of this study was to research enrollment planning models only in English as a second language programs housed in institutions of higher education in Oregon. However, one cannot look at foreign students in ESL programs without looking at general foreign student enrollment. Therefore, this process demands the interrelationship of the admissions officer and the international student services officer. In order to ultimately arrive at conclusions as to the planning practices in ESL programs, it is necessary to begin research with the admissions office and the ISS office to see how ESL is involved in this.

Finally, it is believed that limiting the study to institutions in Oregon will provide more relevant data to these state institutions than will information gathered nation wide and that institutions will be able to use the results of this study to re-evaluate their institutional missions regarding enrollment planning for foreign 
students. In order to carry out this goal, this study is conducted under a cooperative spirit of sharing so that all involved may ultimately benefit from the results.

\section{STATEMENT OF THE RESEARCH PROBLEM}

This research is concerned with enrollment planning for foreign students in institutions of higher education in Oregon, including English as a second language programs. The literature indicates that there are virtually no planning models available for ESL programs to use in determining enrollment. In addition, the literature suggests that there is little policy developed at the institutional level regarding the enrollment of foreign students.

Consequently, in order to observe the nature of foreign student enrollment in colleges and universities in Oregon both in undergraduate and graduate programs and in English as a second language programs, this study acts, in part, as a review of planning practices for these students as described by admissions directors, international student services officers and English as a second language program directors.

The problem has three dimensions.

1. What are institutional enrollment management objectives, both domestic and foreign, and how are foreign student objectives carried out and coordinated throughout the campus? 
2. What is the role of international student services in foreign student enrollment planning institutionally and within their own unit?

3. How does the ESL program manage ESL enrollment and how do they coordinate with other units across the campus?

The aim of this study is to bring together the results of exploration into these three areas in order to present a cohesive picture of enrollment planning for foreign students in our institutions of higher education, including English as a second language programs in Oregon.

\section{REVIEW OF THE LITERATURE}

Planning for the enrollment of foreign students in institutions of higher education involves several areas which when combined provide an overview of the components of foreign student enrollment planning. The key areas include, enrollment management, the migration patterns of foreign students to the U.S., foreign student policy, and enrollment planning in English as a second language programs. The enrollment management component is the overall university approach to enrolling students in an institution. By exploring enrollment management, one can determine an institution's approach not only to enrolling domestic students, but foreign students as well. Research pertaining to foreign student flows and trends provides background data by which to make projections and planning frameworks. Foreign 
student policy in higher education is framed by the principles upon which planning is developed. The planning methods for foreign student enrollment in English as a second language programs are directly related to the three previous areas.

\section{Enrollment Management}

Researchers in the area of enrollment management bring diverse backgrounds and experience to a field that is made up of many different areas of education and requires diversity in researchers and theoreticians. As a group, the authors of such research hold a variety of titles which are listed below in order to give a brief overview of the types of individuals in this field. The titles and positions include, a dean of admissions, a specialist in higher education and marketing, a vice-president for enrollment management, a professor of policy studies, a director of research , curriculum, and planning, a vice-chancellor for student affairs, a marketing research analyst for higher education and a professor of psychology.

These authors have developed theory and have carried out statistical analyses of specific topics in enrollment management. Their work is the result of market research and longitudinal studies of, for example, the factors that influence student college choice. One author has designed and implemented enrollment management software and developed strategic marketing plans for their university. The review of the literature that follows is based on the work of this group of individuals. 
The concept of enrollment management is rapidly gaining acceptance as a means of insuring institutional vitality as universities strive to maintain their share of the market, increase retention rates and counter shifting enrollment patterns. (Hossler, 1985; Beeler 1989). Kemerer, Baldridge and Green have described enrollment management as both a concept and a procedure. As a concept they suggest that "enrollment management implies an assertive approach to ensuring the steady supply of qualified students required to maintain institutional vitality." In terms of a procedure, they describe enrollment management as a "set of activities to help institutions interact more successfully with their potential students" (Hossler 1985, p. 26).

Hossler (1985) holds that a comprehensive enrollment management. system involves the entire campus and not just the admissions director. Primary responsibilities for coordinating the process of enrollment management are variously assigned to a single staff coordinator or an enrollment management division, yet student affairs is increasingly being called upon to master the principles of enrollment management since many elements associated with enrollment planning are most commonly found in this area (Beeler 1989). Hossler and Kemerer (1986) state that in trying to explain how an ideal enrollment management plan might be organized, difficulty arises in forming strict lines between offices on campus. Rather, there will be both formal and informal lines drawn between offices in an enrollment management system. 
The first step in a successful program of enrollment management is the strategic planning process. The guiding force behind the planning process should be the president or other senior-level administrators. These officers will need an understanding of the whole enrollment management system (Hossler and Kemerer 1986; Kemerer 1984-85). Merante (1987) offers that a combined effort is necessary, where part reports to a single department head. He feels this is a realistic frame because "there is not a university in the land which cannot show a chart where lines between departmental boxes connect admissions and financial aid (and everything else)" (Merante 1987, p. 32). Thus, enrollment management is necessary to ensure institutional vitality and all areas of campus must be involved in this strategic planning process.

As is evident from Kemerer's (1984-85) title, "The Role of Deans, Department Chairs and Faculty in Enrollment Management," the underlying idea in enrollment management is the cooperation and coordination of all facets of a campus. Kemerer (1984-85) holds that enrollment management is the responsibility of all who make up the academic community. He points out that a campus may decide to highly restructure the existing process of enrollment management involving departments across the campus, or may decide to house the system under one administrator or division. Departments act as units who need to reorganize their individual missions and goals in terms of enrollment and then work together with the top administrator in order to achieve these goals. 
It is difficult to outline a generic enrollment management system that a university or college could implement because a plan must be tailored to the specific needs and characteristics of an institution. Hossler and Bean (1990) state that after reviewing enrollment management systems for over ten years, there is no one model which outlines how an enrollment system should be set up in an institution. The answers to questions such as who should coordinate an enrollment management system?, depend upon the "needs, organizational climate, and administrative skills available on each campus" (p. 45).

However, there are some basic frameworks that can be considered when an institution begins looking at an enrollment management program. Hossler and Bean (1990) warn that these approaches should not be viewed as "blueprints" but as possible guidelines to follow. The basic frameworks for developing an organizational model as described by Kemerer, Baldridge, and Green (1982) are: the enrollment management committee, the enrollment management coordinator, the enrollment management matrix, and the enrollment management division.

First, the enrollment management committee usually has the job of evaluating an institution's marketing and student retention efforts. There are both advantages and disadvantages to a committee. The main advantage is it can be an educational tool for faculty and administrators about marketing and retention without requiring a large degree of administrative support from senior-level administrators to implement. The main disadvantage is that "at 
most colleges and universities, committees have little influence over institutional policy making" (Hossler and Bean 1990, p. 47).

Second, the enrollment management coordinator is responsible for organizing recruitment and retention efforts. The coordinator is often the director or dean of admissions. Because the coordination model does not call for organizational restructuring and does not require a great deal of administrative support "administrative units such as student activities may feel less threatened and cooperate voluntarily" (Hossler and Bean 1990, p. 48). A disadvantage to this model is it does not provide a "formal mechanism for linking enrollment concerns and the decisionmaking agenda of senior-level administrators" (p. 48).

Third, the enrollment management matrix is a more centralized model than the two previous in that a senior-level administrator such as the vice-president for student affairs is in charge of the enrollment management matrix. Administrative heads will report both to the senior-level administrator as well as to the individual to whom they previously reported. The primary advantage to this approach is enrollment management becomes "the direct concern of a senior-level administrator" (Hossler and Bean 1990, p. 49). In addition, this model does not require administrative restructuring. The main disadvantage is the seniorlevel administrator may not have the time to give to enrollment management concerns, as well as possibly not having knowledge about enrollment management. 
Lastly, the enrollment management division is the most centralized of the models. In this model, a vice-president or associate vice-president is "assigned the responsibilities for all enrollment management activities" (Hossler and Bean 1990, p. 49). Because this model demands a high level of administrative support, most often the president or senior vice-president of the institution must strongly back this model. Advantages include increased cooperation between offices such as financial aid and admissions. A primary disadvantage is the degree of restructuring this model entails. Placing units under the senior-level administrator after taking them away from other divisions can upset smooth functioning.

Hossler and Bean (1990) point out that an institution may apply parts of several of these models in developing an enrollment management system. They caution against focusing solely on finding the proper structure and not on making sure that "an institution has administrative staff with the requisite skills in key positions" (p. 52) to carry out the functions required by certain structures.

These are the frameworks or models that can be followed and adapted to an institution. Regardless of the type of model an institution follows, Hossler (1985) states that the individuals responsible for enrollment management or enrollment planning must have direct responsibility for the following areas: student marketing and recruitment, pricing and financial aid, academic and career advising, academic assistance programs, institutional 
research, orientation, retention programs, and student services. As is clear from the list, enrollment management or planning involves every aspect of a campus. Kemerer (1984-85) says:

There can be no substitute for faculty involvement because it is the faculty that develops programs, establishes articulation agreements with feeder institutions, publicizes departmental programs, and is directly involved with students daily through teaching and advising (p. 5).

The aspects of enrollment management and possible models are extensive yet, no where is there specific mention of how foreign students fit into this picture. On one hand, it could be that foreign students are recognized as part of the student body and therefore are in a sense referred to along with the regular student body. On the other hand, in the list of units that an enrollment manager must have direct responsibility for, specific areas were mentioned but missing was international student services. In order to specifically include foreign students in the enrollment management picture, I would add along with Hossler's eight areas that an enrollment manager should have direct responsibility for international student services and their orientation as well as student services provided for foreign student in the ESL program on campus.

\section{Migration Patterns of Foreign Students}

During the past twenty five years, migration of foreign students to the U.S. has increased almost ten-fold. Despite changes in the migration process that restrict student flows, enrollments continue to grow. As enrollments have grown, there has been a 
change in the proportion of students from particular countries of origin. Higher proportions of students now come from Asian and OPEC nations. From the mid 1950s to the early 1980s, percentages of students from Europe, Latin America, and North America have declined (Agarwal and Winkler 1985).

Furthermore, in the academic year 1988/89, there were 366,354 foreign students studying at accredited U.S. colleges and universities. This represents an increase of $2.9 \%$ from the previous year. During the past several years the rate of increase has been growing, from $1.7 \%$ in $1986 / 87$ to $1.9 \%$ in $1987 / 88$ to the $1988 / 89$ figure. However, in the U.S., foreign students account for only $2.7 \%$ of enrollments in institutions of higher education (Open Doors, $1988 / 89$, p. 1). An important reason to be aware of migration patterns is that just a small number of countries (15) account for $60 \%$ of foreign students in the United States, and "this degree of concentration leaves many in American institutions and programs vulnerable to the impact of policy changes on the part of a handful of student exporters" (Barber 1985, p. 8).

Agarwal and Winkler (1985) describe the determinants of foreign student flows to the United States which include the high quality of U.S. higher education, lack of educational opportunity in the home country and the cost of attending U.S institutions of higher education. They also note some less stable variables affecting student flow such as political upheaval in the home country, racial or religious persecution, and avoidance of military service. Another factor influencing foreign student enrollment in the U.S. is the 
opportunity for study in other countries. When other leading receiving nations change policy, such as tightening admission or raising tuition, it is likely that U.S. institutions will feel an increase in foreign student enrollment.

Whatever the trend in foreign student enrollments, ESL programs will be affected since it is from this larger pool of foreign applicants that ESL programs derive their enrollments. The factors influencing student flows into U.S. institutions of higher education are especially relevant for English as a second language programs.

Statistics on foreign students in the institutions participating in this study appear in Appendix B.

\section{Policy on Foreign Students and Their Admission}

For a historical look at admission of foreign students, we can turn to Elliot's 1969 article entitled "The Dilemma of Foreign Student Admissions," in which he outlines the major obstacles faced by foreign students hoping to be admitted to U.S. institutions of higher learning. Some of his observations still hold true today. One of the main problems is in developing general criteria for admitting foreign students. Established guidelines reflect, in part at least, the philosophy of the individual institution in supporting a foreign student program and because of this, larger institutions are doing more to make admission policies fair for foreign students (Elliot, 1969).

Kaplan (1987) remarks that the issue of foreign student flows into the U.S. has been "floating around unresolved through the 
educational sector for the better part of half a century" (p. 7). Still, Kaplan cites several professional organizations that have consistently been involved in international education, such as the Association of International Educators (NAFSA), the Institute of International Education (IIE) and the American Association of Collegiate Registrars and Admissions Officers (AACRAO). These organizations have consistently encouraged the development of institutional and even national policy during the past forty years.

Even though there is concern on the part of these professional groups and others, "a great many institutions that admit international students don't yet fully understand why they do so and don't yet have any clear notion of what they are actually doing" (Kaplan 1987, p. 8). Rogers (1984) remarks that very few institutions have created a policy of dealing with foreign students and their admission. Unfortunately, this is a problem that has not been resolved during the past 30 years. In 1964, Education and World Affairs appointed a study committee on foreign student affairs in response to requests that the organization make a study of the broad policy issues in the area of foreign student affairs. The following view of the committee illustrates how little has changed in almost three decades:

Since the admission of foreign students to our educational institutions requires greater investment in staff and increased financial resources, our institutions need to be clear about their reasons for admitting foreign students. At present this clarity is rarely found. Policy makers within the same institution often differ sharply over the 
role of their institution in relation to foreign students (Education and World Affairs 1964, p. 4).

Yet, when practitioners do implement policies, it is more often than not reactionary. Slocum (1984) notes that due to U.S. student enrollment increases in particular departments, such as engineering, higher admissions standards for foreign students were being proposed or implemented in many colleges as a way to reduce the competition for U.S. students trying to enter certain programs. On the other hand, some private schools during that time were undergoing a decline in admissions of U.S. students because of costly tuition and therefore were relaxing their admission standards for foreign students (Slocum 1984).

In examining the policies that schools have developed as a result of the presence of a foreign student population, Kaplan (1987) adds that many institutions do not have any special services for the admission of foreign students including assessment of English proficiency. The people in universities whose job it is to provide services to foreign students are not recognized as serving a major function at the institution (Kaplan 1987). This lack of recognition undermines institutional policy with regard to foreign students in that responsibility is not assigned and is therefore not taken. As a result of this passivity, departments serving foreign students are forced to work within a weak institutional framework because they cannot single-handedly implement new policies to effect change. The underlying cause of this problem is that "academic institutions have unconsciously determined not to decide anything in the context of international education" (Kaplan 1987, p. 8). It may be in the best 
interest of the institution as a whole to coordinate efforts to create a sound policy for admitting and serving foreign students.

The subject of standards and responsibilities in international educational interchange is clearly gaining in importance as international education has become an essential part of education in the United States.

It is, however, a component often left to chance for development, refinement, review and direction by individual institutions. Institutional services that support international educational interchange are among those often left to develop without policy direction and management coordination (Quann 1979, P. 407).

In 1964, NAFSA published the Guideline on Responsibilities and Standards in Work with Foreign Students. This manual is intended for both the makers and implementers of policy. It outlines and supports a set of standards that is intended to guide and direct the successful "execution of responsibilities in international student education" (Quann 1979, p. 408). It is NAFSA's belief that:

The establishment of clearly stated policies for international interchanges which are accepted and well understood by those who direct of implement institutional purposes is an essential ingredient in the international education process. Such policy must draw on and relate to the fundamental mission of the institution (Quann 1979, p. 410-411).

The following are considerations the NAFSA Guideline supports as meriting attention when developing a policy on international educational interchange. 
1. The directional flow of students and scholars.

2. The nature and scope of interchanges including the nature and the extent of services necessary to provide for foreign students.

3. The administrative location of services in that foreign student program locations may range from the president's office to an international program unit (Quann 1979, p. 413).

In regard to the students themselves, it is a good idea to determine the ratio desired between American students and foreign students as well as the geographical origin, socioeconomic background and admissions qualifications of foreign students (Quann 1979, p. 414).

Organizations like NASFSA are leaders in establishing standards and guidelines for international interchange. This does not necessarily mean that individuals in institutions who work with foreign students apply the standards and guidelines of NAFSA. The extent to which NAFSA influences those working primarily with non-foreign students may be apparent in the degree of application of the standards and guidelines in the contact that does take place with foreign students.

\section{ESL Program Enrollment Planning}

Presently, intensive English language program directors are responsible for engaging in enrollment planning when asked for budgetary purposes to estimate numbers of potential students to attend their program. As leaders of ESL programs, they are to 
determine and plan for certain numbers of students. How they arrive at conclusions as to student numbers is unclear as it appears that there is virtually no published material on this topic as it pertains to ESL programs. In all of the searches I conducted on ESL enrollment planning, I found only one citation which referred to this topic. Two authors, Davidson and Mead (1986a), have studied the benefits of enrollment forecasting in regard to their English language program and have published the results explaining their forecasting methodology.

Despite the limitations of forecasting for foreign student enrollment, Davidson and Mead (1986a) hold that it is better to engage in some kind of forecast model rather than be reactive to situations which appear suddenly. Although a forecast model cannot predict political and economic upheaval in the world, it can reflect past trends and patterns of ESL enrollment on which to plan for the future. If we can understand the conditions that affect student flow we are better equipped to plan effectively (Davidson and Mead, 1986b).

Although Davidson and Mead's paper is a significant contribution to ESL program forecasting, it is not a comprehensive study since it applies specifically to their English language program. Their conclusions, which emphasize the need for enrollment forecasting systems to be implemented in intensive English language programs, echo the concerns of enrollment management leaders, Hossler and Kemerer (1986), in regard to a whole university approach to effective enrollment planning. 
In conclusion, from the literature, it appears that enrollment management is developing as an important administrative practice, that foreign students are increasingly part of our institutions of higher education, and that there is a great lack of institutional involvement in a cooperative effort to formulate a foreign student policy by which to operate foreign student enrollment planning. 


\section{CHAPTER II}

\section{METHODOLOGY}

\section{INTRODUCTION}

This chapter will review the procedures followed in conducting this study. This is a descriptive study and as such survey methodology was the method selected. The personal interview was determined the most effective means to obtain the necessary information.

\section{SUBJECTS}

In order to gather data on current planning practices for enrollment in state institutions of higher education, I chose five institutions in Oregon for my study. I decided to collect the data from three units most directly involved with either enrollment issues or foreign students on each campus and to interview the head of each unit. The units are: the admissions office, the international student services (ISS) office and the English as a second language program (ESL). The positions are: the dean or director of admissions, the international student services officer, 
and the English as a second language program director or coordinator. The ISS officer was either the director, acting director or associate director. In the case of one private school where I interviewed the program assistant, the interview questions were sent in advance at her request, and she and the associate dean for international students reviewed the questions together before our interview. Thus, the responses I recorded were her own as well as those of the associate dean.

I chose the three largest public institutions of higher education in terms of student population under the assumption that schools with large enrollments would have a need to manage a large student body and may therefore have a system in place to control enrollment. These schools are: the University of Oregon (UO), Oregon State University (OSU) and Portland State University (PSU). I chose two private institutions of higher education in Oregon in order to have examples of planning practices of schools not dependent on state funds. Lewis and Clark and Linfield were randomly chosen among private schools which had an ESL program.

I chose the institution and then the individuals in the positions I identified served as participants. I contacted each person I wished to interview. Once all three individuals at an institution agreed to participate in the study, interviews were scheduled. Interviews were conducted at the respective institutions and were 45-60 minutes in duration. 


\section{MATERIALS}

Three sets of interview questions were formulated. These appear in Appendix A. The question sets had similar characteristics, but were designed specifically for each of the units. The admissions set had thirteen questions, the ISS officer set had seven questions and the ESL set had eight questions. This means that each unit was asked seven to nine questions regarding planning for foreign student enrollment and that the admissions officers were asked an additional four questions about general university enrollment management. I brought the questions to the interview and gave a copy to the interviewee before the interview began. I allowed time for the individual to look over the questions and ask me any questions before we started. If an individual requested a copy of the question set at the time the appointment was made, I sent it ahead of time. Otherwise, they saw it at the time of the interview.

I was given oral and written consent to tape record each interview. I used the same recorder for each interview. Each cassette is labeled with the institution name and corresponding unit, for example, "PSU-ESL."

\section{PROCEDURES}

I followed the same procedure for every interview with little variation. In some cases, I read the questions and in some the 
interviewee read from the question sheet and responded. We each had a copy of the questions in front of us. I kept my input to a minimum except to ask for further clarification or to summarize to check my understanding of the response. Generally, I did not ask participants to elaborate for two reasons. The first reason was in order to use the time allotted to cover all of the questions and the second reason is most participants answered most questions with an adequate amount of information.

After the interviews were completed, I transcribed all fifteen interviews. The average length was eleven pages per interview; thus there was an approximate total of 175 pages of transcriptions. Approximately $90 \%$ of the transcription is verbatim from the recording in order to retain the participant's full meaning, tone and emphasis for use in analysis and quoting. About $10 \%$ of the transcription contains some summary of long examples or information that was not particularly relevant to the question asked. In the transcriptions, summarized passages are distinguishable from verbatim responses, so quoting will be accurate.

Because the interview was taped, notes were not taken during the interview except to record correct spellings of names and organizations reported by the interviewee during the interview.

The environmental conditions at each interview were very similar. All interviews took place during daytime hours on weekdays and all were conducted within $41 / 2$ weeks of each other. In every case $I$ was in an office setting. The interviewee sat in a 
chair in close proximity to me. In only one case was the interviewee's desk directly and completely between us. In three cases I was seated to the side of the desk and the interviewee was seated lengthwise, thus only a corner of the desk separated us. In eleven cases no part of a desk obstructed the seating arrangement. So, except in the one case mentioned there was no physical barrier present during the interview. This facilitated what $I$ perceived to be a feeling of openness toward the interview itself.

\section{ANALYSIS}

After the transcriptions were completed, I grouped them by position. That is, I grouped all ESL transcripts, admissions transcripts, and ISS transcripts. Then I reviewed each one noting important points. Important points were those which either stood out because they were unusual or because they were consistent with the others interviewed within that unit. In the process of compiling the results, I found it necessary to omit some interview questions and to combine two interview questions within the same unit set. There were several reasons for omitting some questions. The reasons range from technical difficulty in the recording to participant responses not yielding sufficient information for compiling results. Finally, I arranged the results of each group of interviews in report form and recorded these in the results section.

The results are organized in three parts. Each part shows the responses and outcome of the interviews with the admissions 
directors, ISS officers and ESL directors respectively. A discussion of the interviews as a whole will appear in the discussion section. 
CHAPTER III

\section{RESULTS}

\section{INTRODUCTION}

This chapter will present the results of the interviews with the three units on each campus that participated in this study. The results are formatted so that the interview question is presented first with the results following.

\section{INTERVIEWS WITH ADMISSIONS DIRECTORS}

1. What are this institution's objectives for enrollment management?

Four out of five admissions directors responded to this question with no apparent hesitation or doubt as to the meaning of the term enrollment management. This told me that four admissions directors were probably familiar with this term and had at least their own working definition of the term. Because there are so many different aspects of enrollment management, it is not safe to assume that in discussing it that all parties are speaking from the same definition. However, in my question line, I was able to 
determine in a general sense, each person's understanding of this term.

UO holds that enrollment goals or an enrollment management plan is to a certain extent coordinated with other systems within the Oregon State System of Higher Education (OSSHE) under the umbrella of the chancellor's office. In 1988-89, the state system set up an enrollment management committee. That committee was charged with the responsibility for looking at a wide range of issues, but focusing really on bringing together the enrollment management plans that were to be developed at each of the several campuses in the state system.

PSU clarified that the admissions office directs only one part of the whole enrollment plan which includes pre-enrollment services, the actual registration process, and all of the retention efforts. In his own words, this officer added, what we've done to kind of put together an enrollment plan here is we have an enrollment cluster and we begin with the director of admissions, the registrar, and the director of financial aid meeting weekly to talk about what's going on in our different offices just to share information and see how we can cooperate. There is a committee right now called the enrollment management committee that is made up of faculty, staff and people in the administration and we are talking about what proper enrollment mixes at PSU should be. As an institution, we haven't asked those questions before, so we don't have a lot of answers for those questions. 
OSU responded to this question in two ways. First, their objective is to meet the enrollment target the State System of Higher Education establishes in order to receive funding. Secondly, a couple of years ago, this objective took on new dimensions when it was apparent they would need to be concerned about their numbers in order to continue to receive state support. Thus, it has always been a goal to meet this requirement, but it has only been recently that they have had to be concerned about doing this.

Lewis and Clark responded in this manner, "I would say our objective is to adequately marshall the resources necessary to maintain what we feel is a critical enrollment institutionally." This admissions officer explained that critical enrollment involves the projected enrollments reflecting retention as well as the accurate assessment of new students replacing graduating seniors.

Linfield explained that enrollment management involves admissions, financial aid, student advising, orientation, and in part, the registrar. They aim to bring these agencies together in order to work not only with the external part of campus, but the internal avenues as well. Their objective is to have some coordinating body or person to bring that together.

Through their answers, schools defined enrollment management in different ways and proceeded to explain the way they use what they consider to be "enrollment management" to fulfill their objectives. However, several institutions said they had not had to think about enrollment management before and that certain factors are now requiring them to think about this. One 
public institution responded to the question that their objective is "to get an enrollment plan. Just to develop one." Another public school prefaced the response by stating that they did not conceive of their institution having a system of enrollment management. It is interesting, though, that although some of the institutions surveyed stated that they did not have a plan, further discussion revealed some hints of newly instated committees or groups to look at enrollment concerns.

Furthermore, due to the individuality of each institution, enrollment objectives were very individualized. Most obvious was a split between public and private institutions. Public schools need to maintain a level of students that is demanded by the state system for funding. As a result of the OSSHE initiative to set up a state level enrollment management committee, institutional committees were organized at individual institutions. The UO committee came up with a plan that calls for increasing the foreign enrollment on campus to $10 \%$ of the total population. Interestingly, the $10 \%$ "just seemed to be the right number" (UO). No other institution stated they had formally decided on a $10 \%$ policy, but all gave indication that $10 \%$ foreign enrollment was a goal to aim for.

2. Who at your institution is involved in enrollment management?

This question was omitted from the results because the responses to this question were not consistent in their focus. That is, 
some directors answered with respect to the whole university and other directors answered with respect to their individual offices. Furthermore, more detailed information as to who is involved in enrollment management came from the responses to other questions.

3. How are departments across the campus involved in enrollment management?

This question assumes the involvement of other departments in enrollment planning. Most schools attributed different aspects of enrollment concerns to various sectors of the campus. For example, it was consistently said that admissions is responsible for admitting new students; however, it was firmly stated by one public institution that it is not solely in the admissions office that enrollment management goes on and that it is a joint effort. This is true especially for the public institutions, where the admissions directors are more implementers of policy rather than the policy makers. The admissions directors are charged with developing a plan to satisfy the parameters set down from above. This means that enrollment management starts with the policy makers. It is important then to ask the question, are the policy makers aware of the impact their decisions have on those who must carry out their stated objectives? For example, when an institution recommends that the international student population represent $10 \%$ of the total student body, is there consideration given to those units on campus 
most directly responsible for international students as to the impact this decision will have on their ability to serve an increase in international students? NAFSA guidelines for standards and principles for professional staffs and volunteers state that "experience has shown that an institution which enrolls 350 foreign students should have the equivalent of one full-time foreign student adviser with clerical assistance and at least one admissions person who specializes in foreign admissions and credentials evaluation" (Quann 1979, p. 412). An increase to $10 \%$ foreign students on a campus could require the hiring of additional staff which monetary resources could not support.

Many directors voiced the opinion that retention is the job of many on campus. Some pointed out the danger of this, as does Hossler (1985), who said that the job of retention is everyone's responsibility and therefore is no one's. Other units on campus most frequently named as participants in enrollment management include the business office, the registrar, housing, and financial aid. All of these units are involved in carrying out the enrollment objectives of their institution. I noticed the absence of mention of international student services (ISS) or the English as a second language program (ESL) or any other departments involving foreign students as being part of the way a campus was linked in going about enrollment issues. It is possible that this indicates foreign students are a low priority on many campuses or at least that when talking about general enrollment issues and the campus network for handling them, that foreign students are not named first because 
they represent less than $10 \%$ of the students on campus and therefore do not naturally come to the forefront in such discussions. Regardless of the reason, it is worth exploring if administrators make foreign students a priority. NAFSA standards indicate that there is quite a variety in the administrative location and level assigned to services for foreign students and suggest that "the placement of such responsibility within the institutional hierarchy will determine its emphasis" (Quann 1979, p.413).

4. What are the skills necessary for the Director of Admissions to effectively manage enrollments?

Because admissions has changed dramatically over the years, so have the skills necessary. Agreeing on what those skills are is not as simple. The diversity in background that directors bring to the job explains the wide variety of responses to this question. Some directors focused on people skills, pointing out that meeting with high school students and their parents required a special type of communication skills. While probably all directors would agree that communication skills are important, there was a division among these administrators as to the importance of possessing statistical knowledge and ability, research skills and the ability to interpret data that have been gathered. One private institution remarked that one really needs to have a fairly keen eye on statistics because after all they are "administrating a pretty big business in terms of enrollment." Conversely, another opinion was 
that statistical ability is not entirely necessary because not only is there usually an institutional research person on each campus who makes predictions, there is also software available. In a more general sense, the director of one of the state schools emphasized that "you need to have the confidence of the whole university." Another very insightful response came from a dean at one of the private schools. He said that he thinks that another skill that is going to be needed is a sensitivity to cultures, not only for the foreign student, but for a multi-cultural environment.

With the past couple of decades showing steady enrollments, the admissions director was not called upon to solve enrollment problems. I believe that up until the present, admissions directors did not really have to think about the skills necessary to effectively manage enrollments. However, as admissions is now becoming a fairly specialized profession, more attention may need to be given to enrollment management training. Based on its needs, it is up to each individual institution to decide how to go about furthering professional development in the area of enrollment management.

5. What is your policy for the admission of foreign students?

Four out of five admissions directors responded to this question by listing the requirements necessary for foreign students to be considered for admission to the institution. These requirements may vary slightly depending on the institution, but generally include transcripts of the equivalent of completion of high 
school, a TOEFL score, and proof of financial support. The fifth admissions director responded that the institution's policy right now is to increase the number of foreign students.

6. Who is involved in foreign student admission?

Every institution has an individual or entity in place with the specific role of evaluating undergraduate foreign student applications. The individual responsible may be the associate director of admissions and/or the foreign credential evaluator. The entity may be a foreign student admissions committee made up of representatives from admissions, ISS and ESL. As far as graduate applications, when individual departments make the decisions whether to admit or not, the admissions office is still involved in determining if the applicant meets the requirements listed in the institution's foreign student admission policy.

7. Do you try to balance the number of foreign students by maintaining a diverse foreign student population?

All schools gave indication that too many students from any one geographic area may not be as beneficial to the institution as diversity in numbers. When any one country is represented by very high numbers, institutions may attempt to balance the population by targeting areas of low representation. This may be done through recruitment or financial aid. First, recruitment can 
take many forms. One way is to set up relationships and networks with under-represented areas. Another is to network through the few students that are on the campus. Secondly, the limited financial aid available to foreign students at both public and private institutions, goes to under-represented areas, notably Latin America and Africa. Oregon State University is an interesting case where recruitment is not used as a tool to balance the international body. OSU doesn't recruit because its foreign student body has stayed at about $10 \%$ without recruitment efforts. It is reasoned that the types of departments and degrees on that campus are so specialized that "the nature of our programs determines who's going to come here" (OSU). It appears that some degree of diversity is a natural result of the types of students a land-grant institution attracts.

The other institutions surveyed also agreed that diversity is a goal, but no director detailed any plan for arriving at a balanced representation of foreign students. One director of a public school stated, "we just kind of look at what we've got and try to figure out what we need to balance it." From the data gathered in the interviews with the admissions directors, it appears that with the exception of using financial aid money or recruitment, there is no structure in place to diversify the foreign student population. So, there is a goal with no stated means by which to achieve it.

8. Do you keep record of changes in the way you plan for enrollments in the past five years? 
Consistently, interviewees underscored that it is the job of the international student services to keep records of foreign students on campus. It is from these records that trends may be shown, thus aiding those attempting to make predictions based on historical data. However, ISS is not the only unit on some campuses with this function. Institutional research may also provide this resource. In addition, the information may be accessible to all other units through a common data base.

9. Have there been any changes in foreign student enrollment due to world events? How have you responded to them?

Each school responded differently to this question. The University of Oregon said that there have definitely been changes, with the most recent being the system-wide enrollment management effort which resulted in the institutional decision to target the number of foreign students. Two other institutions remarked that there had not been any "planning" to change. One private institution admitted that as far as any kind of planning they do for regular admissions, the answer is no. He added, "We fly by the seat of our pants." In contrast, another private college cited their enrollment group as being aware and working with the issue. It seems that although there is a certain awareness level among the directors, there has been no structured plan to have undergone any kind of modification in the past five years. 
10. Have there been any drastic changes in foreign student enrollment due to world events. How have you responded to them?

11. Has there been any enrollment crisis which has caused you to re-evaluate your current system of enrollment management?

(These questions were combined)

China, Eastern Europe, the Gulf War and the Iranian Revolution are examples of changes or potential changes in foreign student population or sudden changes in the needs of certain groups on campuses. Four out of the five schools indicated that their ISS unit is involved in responding quickly to needs of foreign students in such times of crisis. According to admissions directors, whether students are in financial difficulty due to the political state of their country or struggling with issues of war, the ISS offices have shown that serving the needs of foreign students is a priority.

No one said that these events brought about a re-evaluation of their enrollment planning strategies. Some schools are taking steps to prepare for a possible crisis such as an influx of Chinese students. If the Chinese government allows students to study abroad freely, such a decision would have quite an impact on institutions not prepared to receive them. For example, it would be necessary to evaluate their foreign transcripts for admissions purposes. At several institutions there are not enough resources to truly prepare for this in terms of hiring additional support staff experienced in evaluating Chinese transcripts. However, one school acknowledged 
that steps can be taken to prepare from the available transcripts and networking if the need arises.

Some schools have begun to re-evaluate their planning efforts not as a result of an enrollment crisis, but due to "different players" now in the administrative arena. This was a very common theme in all institutions. There was an expressed desire for more discussion about the kinds of students the individual institutions would serve and how best to do that.

Only one school mentioned enrollment projections as one of their planning methods. This director stated that they were in the process of making 3-5 year projections based on the status quo and historical data. The goal of the projection is to determine shortrange enrollment goals by class and level in order to study persistence (i.e., what are the reasons certain students remain enrolled and what is the duration of their stay in an institution), and retention.

12. What procedure do those students follow who apply to the institution, but who do not have the required English proficiency level?

The responses to this question did not yield substantial information. However, the general thrust is that students are considered for admission based on their previous academic record. If that is satisfactory, but the student does not have the requisite English level, most institutions will either admit the student into the 
ESL program or in the case of institutions whose English program has separate admissions, encourage the student to apply to the English program.

13. How is enrollment management handled in the intensive English language program on your campus?

This question was omitted from the results due to technical difficulty during the recording of two of the interviews. Furthermore, participants whose responses were successfully recorded indicated that they felt unqualified to answer this question.

From this question I had hoped to learn what the admissions directors knew about enrollment planning in the ESL program at their institution. Some ESL programs admit students directly into their programs. In some programs, students must first be admitted to the institution. There was indication that admissions directors did not feel qualified to answer this question, particularly in those institutions whose ESL program admits independently of the university or college.

\section{INTERVIEWS WITH INTERNATIONAL STUDENT SERVICES OFFICERS}

1. Do you play a part in enrollment planning for foreign students on this campus? 
The organizational structures of each campus' units of admissions, ESL, and ISS are different. It is important to be aware of this because differences in structure may dictate different ways enrollment planning is handled at institutions.

UO said that $10 \%$ enrollment of foreign students is the president's goal. Enrollment planning in goal setting is an ideal circumstance and this ISS officer does not think that it has been systematically done at that institution. It has been a top down administrative decision. The part he does play is in the recruitment effort and retention programming of foreign students.

PSU said, "not only do we play a part, we play a significant and a major part in enrollment planning for foreign students on this campus or international students on this campus." $\mathrm{He}$ supported this with examples of pre-arrival work that is handled through the ISS office, as well as educational planning service which takes place in the same office. His enrollment planning has to do with the quality of the students' stay at the institution. He acknowledges that a lot of people only think of enrollment planning in terms of charts of numbers, but he thinks of it as that which is necessary for maintaining the foreign student's visa status and successful completion of academic and social experience at the institution. OSU said, "Well, no because there isn't as far as I'm aware, formal enrollment planning that involves students here." She said she used to be involved with the preparation of brochures that were distributed worldwide for the purpose of attracting students from other countries, but several years ago it was stopped due to 
budget cuts. It was deemed a "low priority to actually do things that were specifically oriented toward drawing international students to the university" and in the same category, the graduate school no longer sends catalogs to individual students overseas who request information about graduate programs at this institution. "So, in terms of enrollment planning, I'm really not aware of any; in general, our international student population has tended to be around $10 \%$ of the total student body and it fluctuates but it tends to stay around there."

Linfield's ISS officer, on her own initiative, developed a relationship with the individual responsible for recruiting at her institution. As a result of this relationship, she is now more involved with the recruiting of foreign students. She is on an enrollment related committee that includes the president of the college and the director of ISS. She admitted that several years ago she wouldn't have known anything about this.

As far as the actual admission of foreign students, ISS is not very involved with this process unless there is a special case which requires its attention. This officer does not necessarily want the ISS office more involved with the technical part of admissions, but she did say that her office is involved through recruitment. An example of this is in the effort to balance the foreign student body. "We have to consciously think about who we want instead of saying ok, whoever applies will just be accepted." If they see a trend that they would like to slow down they would encourage students from 
under-represented areas and this may be done through scholarships.

At Linfield, the ISS officer indicated that it is important to ISS to maintain a balance because it affects the ESL program. As an example, they have experienced having a group of students from Asia with low language skills and a group of students from Europe with advanced language skills. Their ESL program offers limited levels, so "when you have the whole group together it creates a lot of problems."

Lewis and Clark's ISS office makes recruitment decisions. They decide what countries will be visited and why particular countries need to be visited. Records are kept of these trips in terms of how many applications came from a visit to a particular school. In addition, they do a vast mailing every year to colleges, high schools, and educational institutions overseas, and then they keep track of who they hear back from.

Aside from the general program operation, the area of recruitment is an area where most ISS officers feel they had the most input and played the largest part in planning for foreign students. According to ISS officers, recruitment includes mailings, writing pre-arrival literature and overseas recruitment trips to schools or fairs. At the same time, they did not seem to view recruitment as part of a system of enrollment management, or at least did not believe that the recruitment was handled in a systematic way. 
When asked if they play a part in enrollment planning, typically the answer centered on recruitment with a disclaimer such as "I don't know it's been systematically done here" and "I don't think anyone ever thought of asking me." It seems they do not see themselves as part of an enrollment management effort, although they play a role in the pre- and post enrollment services.

Only one officer at one institution said that $85-90 \%$ of foreign student enrollment management happens in the ISS office. Although this may be true, enrollment management as defined by this officer centers on academic and support services provided for students. This is definitely an integral part of enrollment management; however, enrollment management involves more than this area.

2. Do you work with any other departments on campus regarding enrollment of foreign students?

In response to this question, only one ISS officer volunteered the ESL program/department as being an entity which is worked with regarding foreign student enrollment. Each other officer looked toward a higher authority in response to this question, citing admissions or a committee made up of the ISS officer, the admissions director and the vice provost for international affairs. While it is true that the campus units such as admissions are one of the cornerstones of enrollment of foreign students, it is interesting that even those campuses which admit ESL students to the 
institution itself and not solely to the ESL program, also did not cite ESL as a unit to be worked with. For those institutions whose ESL program handles its own admission, orientation and services, it is more understandable that ISS would not be as involved because the ESL program is relatively independent. However, there are two campuses out of the five which admit all foreign students first through regular admissions.

Two of the schools with independent ESL admissions are Lewis and Clark and OSU. They both said they work with their ESL department concerning provisionally admitted students or "both program" students. OSU explained that it is not entirely necessary to have scheduled meetings with other departments because "you make strong personal professional relationships with those in the university who are advocates for international students and meet with those people when necessary."

Linfield and PSU cited units on campus such as housing and the business office that are contacted concerning foreign students. PSU also said that they coordinate all across campus. Their ISS acts as a referral source, directing foreign students to various units on campus when the need dictates this. They also coordinate with the ESL department especially in terms of orientation and the timing of placement exams.

An example of planning and coordination was illustrated by PSU. Fall term, foreign students frequently arrive after registration and find needed courses already filled. In response, ISS initiated arrangements with other departments to reserve places for foreign 
students. Making such provisions to ensure the successful registration of foreign students is an example of an institution providing for student needs once they arrive on campus.

Conversely, an institution could face a predicament if the institution admits foreign students but does not provide for their needs upon arrival. This dilemma is illustrated by this hypothetical situation: Is an ISS officer to say on the one hand, "because you're foreign students, you have to be enrolled full-time, but the classes you need to take are not available; so, you'll have to take a lot of hours of other things that you don't necessarily want to take?"

Other departments are also involved at UO. UO has what they call a "90s Committee" which includes the ISS officer, the admissions director, and the vice provost for international affairs. This committee meets to discuss international issues. Also, at UO, ISS gives their literature to all departments so when requests come, individual departments can send international information as well as departmental material. "In that sense, we're supporting all of the departments" (UO).

There are strong examples of ISS initiating coordination between units on campuses in regard to foreign student enrollment planning. Little mention was made of coordination involving ESL, but it would not be fair to assume on the basis of this question only that coordination with ESL does not exist. It appears ISS takes an active role in supporting coordination. 
3. Are you ever consulted by other departments for trends or migration patterns of foreign students?

It appears that except for occasional curiosity, ISS is not consulted by other departments for trends in foreign student population. Although one institution gave indication that it has happened, it seems to have been a rather isolated incident and not indicative of campus-wide departmental interest.

There is dialogue at UO and OSU between some departments and ISS. For UO, certain departments such as Business and Journalism are professional schools who do have control over who they want to admit, but as far as formal consultation, "I think we do a lot of talking informally because we're on the phone a lot with them about exchange agreements and it comes up in passing" (UO). At OSU, on an occasion when a science department consulted ISS for a trend, ISS in turn consulted other departments across the country. This is a positive example of networking and mutual support among ISS offices.

PSU said casual questions are asked but "not in terms of an actual purposeful fashion of planning or in terms of the interest of having a special group of people." Similarly, Linfield replied "very seldom" are such inquiries made. Out of curiosity questions are asked from time to time, but "it's not a regular thing I get requests for." Slightly different was Lewis and Clark's response that admissions consults ISS for international student records since it is ISS that compiles statistics and circulates them every term. 
It seems that information is exchanged through informal conversation more often than through formal consultation. This may be because there is not a perceived need on the part of other departments on campus to be concerned about foreign student trends on campus even though those foreign students may very well appear in high numbers in various departments across campus.

4. Does your office consult with the English as a second language program on your campus in determining foreign student needs at your institution?

Having a cooperative and collegial working relationship with others in international areas on campus seems to be a very important part of functioning in an international field. Because so much gets done informally, it is almost crucial to have trusting relationships with other areas. This has not always been the case for all departments at all times. Every person interviewed voiced their pleasure in who they work with and that different "players" in the past didn't always help to bring about such positive results.

PSU affirmed by the following statement that there is constant communication, "I think this networking has helped very much. I am pleased to say that $I$ think this kind of coordination and cooperative work has helped us to more profitably serve our students." Along the same line, Linfield's program is in-house, so it is part of the job of the ISS officer to keep in touch with the ESL 
director. "I'm the liaison between her program and the rest of the academic program."

Conversely, OSU has a reactive relationship with their ESL program. If a problem comes up then there may be contact in finding a solution. For example, if a foreign student in a regular university course is not able to work at the level the professor feels is necessary, the professor will often times contact ISS who will in turn contact the English Language Institute (ELI) to arrange for further English work for a particular student.

Similarly, Lewis and Clark's ISS handles foreign students separately from the ESL's foreign students except for "both program people," which refers to students enrolled in both regular university courses and ESL courses. They each address the needs of their students, separately. The ISS officer comments, "Their students are their students. If they're here to study English, they don't really have any thing to do, not with our office." It is apparent that this institution has all the resources in place to be able to do this in that the ESL program is equipped to handle all of their own foreign student matters so that they don't rely on the expertise of ISS.

ESL directors and ISS officers all voiced the existence of a mutually helpful and cooperative relationship in the limited or extensive contact they have between their respective units. Also, it is worth remembering that it makes a difference who issues the I20 s and is responsible for making sure students demonstrate academic progress according to visa regulations. If ISS handles all immigration matters, there will be more interplay between ISS and 
ESL. If the ESL department does that, there may be less intervention by the ISS office.

5. Is your office in contact with other international student organizations such as the Institute of International Education which are concerned with studying foreign student flows?

In general, all of the ISS offices are in contact with international organizations such as the Institute of International Education (IIE). Several institutions have students sponsored by those organizations. The ISS officers do not necessarily consult those organizations; instead, they prefer to confer with officers at other institutions. Nevertheless, publications coming from IIE help ISS to know their market, which is foreign students, and to know the changes and demands in this market.

More specifically, the three state institutions replied very positively and added that not only do they receive information from these sources, but they feed information back to them as part of their professional responsibility to contribute to the continuation of research in this field. In keeping with this, one institution praised the electronic mail available through NAFSA which allows ISS officers to share ideas and insights which strengthens the quality of service offered to foreign students. A private school mentioned a local organization, Northern Oregon International Student Affairs Association (NORISAA) which helps ISS to know what is happening 
locally, which may be more relevant and useful than nationwide trends, especially on the West coast.

International organizations are sources of professional support for ISS officers. All ISS officers responded very favorably toward them and the value they represent in the field of international interchange.

6. Foreign students who are enrolled in the university come to you for the services you provide. How do you plan for those services? Do you react to the degree of need after the students are here? Do you anticipate needs based on the previous year(s)?

At most institutions the student services programs have been in place for a long time so that there is not a need to frequently reevaluate all of the services. ISS units generally feel they are always doing needs assessments. In response to this question one institution replied, "It's just always a kind of evaluative thing."

In planning for services, OSU has structured weekly staff meetings. However a lot of "real information" comes from informal contacts. Both OSU and UO said that at professional conferences such as NAFSA there is a chance for considerable informal sharing of information. OSU said that sometimes formal meetings are a barrier and sometimes they are really appropriate and this officer thought that a good mix of the two is most advantageous.

Especially at small schools, with the arrival of special shortterm groups, students' needs change depending on the group of 
students. What was successful with one group may not work with the next. Therefore, one must be flexible. One has to be prepared with a lot of ideas and be flexible enough to adapt them to each group.

The general feeling among ISS officers is that the repetitive nature of the services provided greatly reduces the need for formal planning or "re-planning" of the services already established. Furthermore, it was indicated that one can not plan for that which cannot be anticipated.

However, it is important to engage in self-evaluation from time to time to determine if the reason for no new planning is that everything really is running smoothly, or if a comfortable acceptance of the status quo is preventing further program analysis from taking place.

7. Do you engage in any kind of trend analysis whereby you watch the enrollment trends by certain countries or kinds of foreign students and make predictions based on this for your own use in structuring your office or the services you provide?

Responses to this question were mixed. Some officers believe that it isn't really necessary to do trend analysis because there are not big increases or decreases in numbers; therefore, trends are not watched in anticipation of surprises in terms of numbers. Others expressed a great desire to do this, but said that due to a lack of resources the current state of trend analysis was unsatisfactory. 
Each school had a unique variation to their response, which is apparent in some of the comments that follow.

For UO, the goal to have $10 \%$ of the population foreign students means that "an international student advisory committee may be on the way to deal with subsequent issues such as how will an ISS office handle a sudden jump in enrollment."

Linfield said, "There is no real purpose for me to keep track of it all of the time." It might be used for meetings, "otherwise, I wouldn't actively go look for it."

OSU reported that they used to keep very specific records about students from countries and regions. This officer went on to say that it was always very interesting and would show the shifting patterns and was "very reflective of what was going on in the world."

PSU said that limited resources in terms of time and staff prevented more analysis from being carried out. He explained that analyses are done, but not as often as he would like. "The interest is there and if there comes a day I have the resources to be able to do that, I think that would be highly, highly valuable."

The relative importance of trend analysis is different for each institution, varying from there being no real purpose in it, to it being highly valuable. The reason for variation may be due in part to institutional characteristics of the size of the foreign student population. Smaller institutions have much greater ability to be flexible in response to foreign student trends, whereas larger institutions by virtue of their size may not have this ability. 


\section{INTERVIEWS WITH ENGLISH AS A SECOND LANGUAGE PROGRAM DIRECTORS}

1. Do you have a system of enrollment management for your program?

No school has a defined system of enrollment management in operation. This conclusion was arrived at because in response to this question, no director immediately began to outline their system. Each director could explain components of their approach, but it was determined from their responses that no defined system was in place.

The following are some examples of the kinds of approaches currently in effect. UO and OSU monitor the number of applications they receive both totally and from different countries. They have a sense of changes term by term which helps to predict, but they never know how many students are actually going to come. However, they do look historically to see how many came the previous term and how many I-20s were issued. At Linfield, the ESL department's enrollment is controlled by the university admissions office. At Lewis and Clark, their system is defined by their standards, not specifically by number, in that their strict admission criteria help to manage their enrollment. They have data control approaches which include surveying all students around the 7 th or 8 th week of the term to determine the number of returning 
students. UO also uses this approach, but said that it does not reflect an accurate number as a long period of time elapses between the 8th week and the start of the new term when students may easily change their minds from what they answered on the survey. PSU said that although they work from projected quotas to handle enrollment that this didn't amount to a management plan.

Although no school had a defined system of enrollment management in place, they considered the approach in use as "the system" and therefore responded as if that were in fact their management system.

2. Who is responsible for responding to enrollment concerns for the ESL program. How has this person been trained for his/her position?

The responses varied to this question. Each director had a different approach in answering this question, but usually the answer centered on the director him or herself, or that it was in the hands of another unit on campus. The following are excerpts from the interview.

UO responded that there are pockets of responsibility and that although ultimate responsibility rests on the director, each participant feels responsible for "her little area of domain." Similarly, PSU and Lewis and Clark said that the director (coordinator) is responsible. OSU said along with the director there is a foreign student advisor and a classified person who work 
closely together on enrollment. Interestingly, Linfield stated that it is really just admissions. However, if it is a question of actually admitting a student, the director of ISS and ESL may become involved.

In response to the second part of this question, all schools said that the people responsible for enrollment planning learned on the job. It was mentioned that this is true in part because it is necessary to look at the particular concerns of one's institution when planning for enrollment. However, it was mentioned that some had attended workshops put on by organizations such as NAFSA, which serve as a source of direct training. One school official voiced concern that they really had no formal training for this part of their job as an administrator. This official went on to say that neither has their institution provided training opportunities nor opportunities to learn from each other how to better respond to enrollment concerns. Another institution explained that if one of the administrators working with ESL enrollment no longer wanted the position they were in, then they would ask another teacher to do it. As far as training the teacher might have, this director said, "to a certain extent there is preparation for that because the person who's in the job now makes quarterly reports about what our enrollment is both totally and by country, comparing to the recent past and analyzing by country." It was reasoned that because these reports are made available to everybody on the faculty, everyone has an idea of the kind of 
information that the person in this position needs to produce and thus what makes up the content of the position.

Every institution's make up is slightly different in terms of responsibility, but generally, the director was the responsible one. Interestingly, all cited on the job training as the means by which they became capable of handling enrollment management. It is worth questioning if program management could be more effective if there were more training as well as if this is a source of professional anxiety that could be reduced or alleviated if more institutional coordination supported program management.

3. Is there any coordination between your ESL program and the admissions office (or other offices on campus) with respect to enrollment planning?

Differences in the organizational structure of the ESL program within the whole institution became apparent in the responses to this question. Answers were individualized based on the characteristics of each school. Responses ranged from very close coordination to virtually no coordination at all.

At UO and OSU, ESL students are admitted to the language institutes specifically. Both of these programs spoke of limited coordination with respect to enrollment planning. UO said that they send materials to ISS which does I-20s, but only the ESL program makes enrollment decisions. OSU responded that there isn't really any coordination because their ESL students are not OSU students. 
Except for the students who are provisionally admitted to OSU, there is no connection with OSU in terms of planning for certain numbers of students.

PSU answered that ISS and admissions (international admissions) talk frequently, but that this is not really coordination about enrollment planning. When organized communication did take place it was perceived to be very reactive and not pro-active in the sense that once it was established that having more foreign students would be a positive choice for this institution, the concern centered around how many students should be enrolled, rather than how much the system can bear and what has to be adjusted within the system to provide the greatest number of services. "That's what I would say is planning and that's not at all what seems to have been happening."

Both Linfield and Lewis and Clark revealed the existence of a great deal of cooperation between units. At Linfield, the ESL director sees every file of every foreign student, as does Linfield's ISS. Lewis and Clark said there is definitely coordination in several respects. There are two different admissions committees. One is for students applying to the language institute only. It is an in-house committee which has as representatives two other members of the Lewis and Clark community. The director of the language institute, sits on the international admissions committee for the undergraduate program for students who will come first to the language institute and then transition to an undergraduate program. This is offered as an example of coordination between ESL and 
admissions in that they both coordinate in terms of general guidelines that they want to look at for the institution as a whole. Because ESL is considered part of the institution, they usually are involved with the admission's office and the registrar's office.

The private schools indicated much more coordination between campus units than did the public school's ESL programs. Because a large institution has so many more numbers to deal with, they cannot be as individualized as Linfield, for example. The public institutions could not really describe formal lines of coordination or communication that probably should exist.

4. Are you asked by higher governing departments to forecast ESL student enrollment for budgetary purposes?

This question was omitted from the results because the responses as a whole did not provide enough information to adequately treat this question. I had hoped to learn if ESL directors were responsible for forecasting enrollment for units outside of the ESL program. It is hypothesized that if forecasting for higher governing units were necessary, enrollment projection in the ESL program may receive more attention.

5. Does your program have a maximum number of students that it will accept in any given term? 
This question was trying to determine whether or not programs had thought about the numbers of student they could handle and serve in a satisfactory manner. It was trying to see if programs had thought about what their capacity is in terms of staff, resources, materials, classroom space and so on. Most of the responses did not address the question in this way. Most knew what would constitute "too many" students, but it appeared they did not have an immediate response of what happens if that should occur. In general, they defined "too many" students as a number that would place too many demands on the program and institutional facilities. It seemed that programs did not feel that this would ever happen and therefore did not really merit much attention. The following are examples of the variations in response to this question.

UO indicated that they would limit enrollment only because of a lack of classroom space and faculty offices. However, sometimes they admit more than their target number if they do not anticipate a high show rate.

PSU offered that they do not have officially listed caps, but if there were too many students for the sections available, they would have to turn students away. Students need to be accepted in PSU first and the admissions restrictions are conservative enough that there would not be huge increases term to term. There is a new deadline for foreign students which requires all materials to be submitted six months prior to the term they wish to enroll. This 
gives adequate time to prepare should there be indication of a rise in the number of applicants.

OSU responded that they have tried to figure out what the ideal size is, but it is hard to do when "you don't know who is actually going to show up." There is a cut off point for the issuance of I-20s, but even with that there is no guarantee as to the show rate. Similar to $\mathrm{UO}$, they issue a lot of admits by making assumptions based on past years about how many students will likely show up. "It's an inexact science, and we have a tendency to go over the limit."

Linfield said, no, that their program is too small.

Lewis and Clark replied that there is a general number, but they do try to limit enrollment. Because of institutional limitations, it's best not to have more students than the institution can accommodate.

For several schools, institutional limitations would apparently be the main reason for setting a maximum number of students. Conservative planning and experience in watching changes term by term and show up rates help to avoid the need for limiting enrollment.

6. Do you actively seek to maintain a balance of students by country of origin through recruitment?

All schools said they would like to increase diversity. However, there was almost no mention of the motivation behind 
diversity. One of the only reasons articulated was that too many students from one culture/language group can make an institution and/or ESL program unattractive to some students. The question did not ask to justify the decision to diversify, but the responses given may indicate an assumption that diversity is desirable, with little thought as to why this may be so.

As far as achieving or maintaining diversity, recruitment is the common method employed. Areas of low representation may be targeted through recruitment trips to foreign countries or by advertising in publications. However, there seems to be no conclusive decision on the effectiveness of advertising. Schools can give examples of advertising bringing in and not bringing in students. No one wholeheartedly recommended this approach, yet, in a competitive market, a program must see where others are advertising. They don't want to be the only ESL program in Oregon not in a particular journal. The most effective method of advertising is to target a certain population who is known to read a particular journal. In one case this was done and in fact brought many students from the area focused on.

Another strategy is to develop relationships with areas that the program would like to have more representation from or continue to maintain good contact with graduates who have returned to their countries. Lewis and Clark reported, "We have a program through which student alumnae are active in alumna clubs around the world and they certainly promote Lewis and Clark." This is evidence that a program needs to put effort into existing 
relationships because "you can't just sit back and assume that demand will take care of you without making some active effort in your marketing" (OSU).

However, not all schools have been able to follow these strategies due to lack of formal planning in this area. There is evidence that discussion on this topic is taking place, but for some schools, that is as far as it has come.

7. Does your department (or institution) watch the economic and political relationships among countries to predict student flows?

All participants agree that at least it is "nice to be aware." Some feel being aware can not change anything because even if the political and economic scene is observed, it does not help in planning when something such as the Gulf War happens. One public school asserted that the whole university doesn't watch, but their department does. Another public institution held that becoming aware that enrollment is tied to political and economic world events can help one to develop a system to handle changes. One institution commented that they refer to publications such the NAFSA Newsletter to learn about trends. This institution said about NAFSA, "they do make predictions for you, for us, so we don't have to be economic and political experts. There are a lot of people who are actually experts. So a lot of information would come from overseas." 
It appears that there is a feeling of powerlessness over world events with respect to planning for foreign students, and that the best alternative is to refer to publications that can help to inform institutions of possible trends as a result of world events.

Collectively, ESL directors suggest that because merely being aware does not give one the ability to predict trends on one's own, it is important to use resources such as NAFSA which offer expert information. Also, it was recommended to be in touch with other institutions in one's region to know if what is affecting one's own department is also affecting another's. In this way, directors can consolidate information in order to work together in finding solutions to shared concerns. Finally, while it is true that some world events happen quite quickly such as the Gulf War, others, such as in China, and Eastern Europe, have been changing over time and have allowed planners time for some discussion and hypothesizing.

8. What happens if there is a dramatic shift in enrollment either up or down?

Most program officers indicated that a shift up would be welcome in most circumstances. It would bring in more revenue and possibly more diversity. It may allow part-time teachers to be hired full-time. However, a danger of an increase too large is that it would put a strain on every part of the system. 
Institutions have controls in place to manage a large increase. PSU has set in place a six month prior deadline for foreign students. ESL students fall into this category. UO has a month in advance cut off in their ESL program. ESL programs issuing their own I-20s can control for increases by limiting the number they issue.

A shift down has more negative implications than a shift up. This is especially true for self support-programs. Also, a shift down may have long term enrollment implications for the entire institution as students in the ESL program may be at the institution after ESL training, resulting in an impact of up to five years.

Finally, another difficult problem would be making staff reductions especially of those individuals on contracts.

Except for an unexpected world event, most institutions hold that their enrollment just doesn't change enough to warrant such formal planning. Also, they have some mechanisms in place to handle increases and some to handle decreases. 


\section{CHAPTER IV}

\section{DISCUSSION}

This chapter will synthesize the results of the three unit interviews from the preceding chapter and will address significant areas revealed through the interviews.

This study set out to find out what institutional objectives are for enrollment management as viewed through the implementation practices of officers in three units described in this paper. The results suggest that directors and deans of admission are aware of the concept of enrollment management, but only recently have they had to think about it. Enrollment management is fairly new and admissions directors have an understanding of what it consists of, but the degree of formalized enrollment management planning as described by Hossler $(1985 ; 1990)$ varies depending on the institution. Results of the interviews suggested that in many cases not only have domestic students not been considered, neither have foreign students. Some institutions indicated that before attention is directed toward the foreign student body, plans have to be made for domestic students.

Admissions directors at the state institutions indicated that the State Board had called for a system-wide enrollment 
management plan. I consulted the Oregon State System of Higher Education (OSSHE) Board Minutes to gain further information about the enrollment management plan and to see if it included foreign students.

After review of the OSSHE Board Minutes from the past five years, the following was gathered. On April 21, 1989, a proposal went before the Board stating that:
Although the State System has experienced significant enrollment growth during the past four years, it has not heretofore needed to consider an enrollment management plan. Due to budget limitations for the 1989-1991 biennium, however, all campuses are facing a situation in which enrollment must be stabilized or reduced. The Chancellor proposes that institutions no longer enroll students for whom the State System will receive no General Fund appropriation; thus the need for an enrollment management policy (Minutes, p. 202).

The staff recommended that the Chancellor be authorized to implement an Enrollment Management Policy which would call for each institution to manage its enrollment so that it would be consistent with the Board-approved admissions policy (Minutes, p. 204).

On October 20, 1989, the Minutes reported that the Chancellor indicated that the "discovery of how to handle enrollment management and enrollment ceilings might extend over two to three years before it was fully developed."

On January 18, 1991 the Minutes spoke about international exchange programs. It said, "The international dimensions of 
education are becoming a national priority," and, "The nation's economic as well as political security is closely related to our ability to compete in the global marketplace and understand what motivates those with whom we interact in other countries." The international focus seems to lean only in the direction of US students going abroad and developing international aspects of course content, faculty and student exchange, and research programs addressing international topics. If the international dimensions of higher education are becoming a priority, it must be recognized that foreign student coming to the US are a part of that priority. However, the Minutes' focus on enrollment management and international education did not include any mention of foreign students enrolling in US institutions of higher education.

It is my assumption therefore, that attention is directed toward the largest percentage of the student population. Still, there are problems related to domestic students also. This study comes at a time when resources, energy, and time are all directed toward the US student to continue to attract them in light of the recent program cuts and tuition increases. Admissions directors know that foreign students represent an important percentage of the student body and they must be included in planning. But, it seems that because they represent a relatively small number in comparison with the entire student body, they sometimes get overlooked.

If admissions is concentrating on US students, the units who are aware of foreign student needs and concerns are in the best place to act as the advocates for this population. If foreign students 
are welcomed on campus, there needs to be just as diligent planning for them as for domestic students. This sentiment has spanned the decades and remains a strong guiding force behind the work of foreign student service providers. The message that Education and World Affairs advocated in 1964, in the following statement is consistent with the beliefs expressed by international student services officers today:

When we welcome foreign students to our institutions, we bear other responsibilities--to give these students an education that is in the highest traditions of American scholarship, to pay attention to their special needs, to try to make sure that in coming the long distances to this country from their own they are not wasting valuable money and time being inadequately prepared and poorly guided (Education and World Affairs 1964, p. vi).

ISS and ESL are potential institutional advocates for foreign students. They are in an appropriate place to make sure foreign students are planned for and not swept by the wayside. There are examples of ISS and admissions working together before enrollment management came about or before the OSSHE Board called for the organization of institutional enrollment management committees. Because these efforts have not necessarily been coordinated with total institutional involvement or support, this has led to frustration by some individuals because lack of involvement often translates into lack of change.

As a result, ISS and ESL need to have the support of the whole institution and the institution needs to make foreign students as much of a priority as any other student. To give support, 
admissions may want to include foreign student advocates in the decision making and teach them planning procedures so it is an institutional effort. More than one individual in ISS/ESL voiced concern over the lack of formal training available. That is why admissions may decide to coordinate its experience and influence with ISS and ESL's extensive knowledge of foreign students.

Not all ISS and ESL directors have considered either more coordination or its benefits. When ISS officers were asked if ISS works with other departments in enrollment planning for foreign students, four out of five ISS officers did not mention ESL as a participant in the framework for foreign students. Foreign students in ESL programs are potential regular students, in which case they would be under the care of ISS. It may be that ISS officers do not see themselves coordinating with ESL in terms of enrollment planning but when asked if they talk with ESL in anticipation of foreign student needs, all responded very positively about the cooperative and cordial relationship between the units. This is clearly because they are supporters of the same interest. It is apparent that the working relationship is successful, but there does not seem to be a purposeful coordination of resources between ISS and ESL to plan for foreign student enrollment.

The individuals holding positions in admissions, ISS and ESL work well together and many (if not all) attributed success to the "players" involved. This may be a reason why no large scale plan is in place. It is possible that as a result of dedicated players who are aware and take initiative to make things happen, a formal structure 
has not been designed for the enrollment management of foreign students throughout an institution. One private school's ISS was not at all involved in foreign student admission and recruitment until they took it upon themselves to seek and find out about this area. The degree of success achieved within the current system is admirable, but how efficient is a structure if its success is attributed to the combination of players and not to the strength inherent in a well-planned system that would continue to operate efficiently regardless of the players?

One more reason there may be little formal planning in many of the three units for foreign students or between units is there is not a sense of urgency to define this. Responses from all units indicated the following three very revealing elements. First, there are not changes in the day-to-day operation of individual units. Secondly, instead of upgrading planning, time is spent on the enormous amount of routine matters as well as the immediate matters that demand full attention. Thirdly, watching and being aware of trends is appropriate, but no amount of planning can control for unpredictable events.

Given all three of these reasons, as accurate as they must be for those interviewed, formal planning does not have to be only in response to or in preparation for an event or change; it can help to define one's own standards and goals.

The end product of an institution's effort to define its foreign student policy, the statement itself, is actually of less importance than the process used to develop it: In thinking through various rationales and options, the 
institution undergoes an enlightening period of self-study analogous to the valuable learning experience encountered in an accreditation review. The process should, therefore, enable the institution to heighten awareness with respect to its goals and how it seeks to achieve them and that consciousness-raising process ought not to end once the policy statement is prepared (American Council on Education 1982, p. 53).

At the heart of developing a policy statement is the issue of diversity among the foreign student population. Diversity in the foreign student body is a commonly expressed goal among admissions directors, ISS officers and ESL directors. In fact, admissions and ESL were asked specifically if they actively seek to maintain a balance of foreign students on campus. According to admissions, answers ranged from not actively doing this, but thinking about it to definitely doing this. Only one institution offered any explanation as to why they might favor diversity explaining that it would not necessarily be in the best interest of foreign students to have too large a group from one country. Some ESL directors answered affirmatively, but did not address the reasons behind it being desirable to do this. One school unit said they have gone to the extreme of setting enrollment caps to regulate diversity, but offered no explanation of why a diverse student body is important to the campus.

I believe there is an assumption that diversity is good because it enriches the campus. However, does a diverse group of foreign students really enrich the campus if no integration takes place? Before arriving at conclusions as to why diversity is advantageous or not and whether time and energy should be expended balancing 
the foreign student population, it is necessary to look at a more fundamental question. That is, what is the purpose of inviting foreign students to our campuses? By attempting to answer this question, it may be possible to arrive at some conclusions about admitting foreign students to institutions of higher learning. Then we can determine if motivational interests are national, educational, economic or cultural or a combination of these.

The American Council on Education Committee (ACE) found in its study that foreign students are "all too often an unrealized, unidentified and unintegrated resource for relieving the startling lack of knowledge among domestic students about international matters" (ACE 1982, p. 4). Before deciding why foreign students come to U.S. institutions, it needs to be determined who is in charge of making policy, whether it is the responsibility of the state system or individual institutions. ACE holds that the responsibility for developing strategies to deal with foreign students is primarily that of individual institutions. However ACE predicted in the early 80s that the state governments would play a larger role in the years to come (ACE 1982, p. 26). Since there has already been some discussion of the responses of the participants as to the reasons for having foreign students, there will be a shift in focus to a public record of institutional missions and state system mission to look for indications or statements of motivations or reasons for having foreign students here.

The Oregon State System of Higher Education (OSSHE) is a planned system with a centralized administration which provides 
long-range planning to its member colleges and universities. It is governed by the State Board of Higher Education whose function includes determining system-wide policy and establishing institutional guidelines. It is planned so that each of the eight campuses has its own specific mission and is coordinated with each other for mutual support and regulation of not overlapping programs. The three public institutions in this study are a part of the Oregon State System of Higher Education. The two private schools are not.

Planning takes place both at an institutional level and at a state system level. If the OSSHE Board could develop a policy from which individual institutions could adapt their own resources and programs, this would be consistent with the state system's organizational structure of mutual sharing and support.

The Strategic Plan is a published document for Oregonians on the missions and goals for the State System for 1987-1993. It describes the assigned institutional missions and strategies as well as those of OSSHE. Interestingly, for the three public institutions in this study, in their assigned missions statements, there is virtually no reference to foreign students. There is mention of international or foreign study abroad programs for American students to study overseas.

Next, under a section called "Guiding Principles in Implementing Its Mission," there is a heading entitled, "Commitment to Cultural Diversity." Here it states: "Educated men and women must be prepared to succeed in an increasingly 
heterogeneous environment. The State System is committed to strive for diversity in its campuses' student bodies and faculty" ( $p$. 4). This does not appear to include foreign students since it doesn't specifically say so; it more likely refers to ethnic minorities. In a sub-section there is mention that foreign students do come to the campus as a result of exchange programs, but there is no statement as to the intended purpose for having foreign students on these campuses or goals for their being there.

In a section detailing the characteristics of the students in the OSSHE system with predictions for the future there is no mention of foreign students. This section focuses on the characteristics of students at Oregon institutions, but does not include foreign students even though they are a part of the student body.

In Chapter 3, "Strategic Planning and Assumptions about the Planning Period, 1987-1993" there is a section called "Enriching the Campus Environment" and it states:

Institutions will increasingly strive to build diverse student bodies and faculties. Attracting foreign students as well as faculty with foreign experiences will assist institutions to build a desirable multi-cultural learning community, which will benefit student, faculty, and staff as well as local communities (p. 28).

Again, just having foreign students will not build a multicultural environment by itself. It takes continued effort by ISS and ESL and others to carry out this mission.

Educational Excellence is a major goal of the state system. The Board of Higher Education has adopted a list of standards that 
institutions should consider in examining the quality of their programs. The Board points out that numerous problems will affect the ability of institutions to provide programs of instruction, research and service of the highest quality during the planning period (p. 33). One of the recommendations concerns foreign language teaching in the Oregon system. It is discussed that foreign language study is extremely valuable not only as a tool of communication, but the cultural awareness and contribution it makes to the global society. Although not specifically about foreign students on campus, it is this kind of forethought which expands an institution's ability to serve the foreign student. By recognizing the needs of domestic students in a global society, it follows that a look at the role of the foreign student would be appropriate and an integral piece of the puzzle.

In chapter 7, under "Programs to Strengthen Oregon's Economy," it is stated that "several goals dominate our efforts to provide programs that will strengthen the state's economy during the planning period" (p. 51). It goes on to specify one of these goals which is "to strengthen programs that will contribute to the state's developing international trade interests" (p. 51). International trade interest, linked with education is a sound goal; however it may merit some evaluation to determine the extent to which international education is functioning as an economic tool.

Finally, the State System presents its, "Accountability of Higher Education Programs" (p. 59). It explains that, "accountability in education literally refers to the educational system's accounting 
for its actions' that is, providing on a periodic basis a public explanation of its activities, conduct and discharge of responsibilities" (p. 59). It goes on to say that, "The system's colleges and universities must provide evidence to the public of their performance, building credibility and public confidence with taxpayers and consumers that it is indeed holding up its end of the public trust" (p. 59). As a consumer and a foreign student advocate, I conducted this study in one sense to seek evidence of the system's commitment to foreign students in institutions of higher education through specific units on campus that work closely with foreign students.

As far as the private schools, it is more difficult to speak in terms of large governing boards such as the State System has in place because this does not exist for the private institutions. Those institutions must be looked at individually and evaluation and change must originate within the institution. However, the private colleges are really in a different position with respect to foreign students than are the public schools. One private school has cultivated a reputation of commitment to foreign students which was revealed through the interview process. The other private school has a strong international focus and the ability to provide individualized attention to each of the foreign students on its campus. These qualities do not take the place of formal enrollment planning, but do compensate for its absence.

In conclusion, this discussion presented some underlying themes which resulted from the interviews. In the recent interest 
in enrollment management by administrators, foreign students will need to be a part of that. ISS and ESL are engaging in a lot of positive activity for foreign students, but ISS may need more institutional support to carry out its function and ESL directors have not really defined a system of enrollment planning instead relying on historical data and intuition. At the heart of the matter is the underlying reason for having foreign students on campus because if units have different goals, problems will likely occur. 


\section{CHAPTER V}

\section{SUMMARY, CONCLUSIONS, AND RECOMMENDATIONS}

\section{INTRODUCTION}

This chapter will present a brief summary of the study, conclusions resulting from the findings, and recommendations for further action.

\section{SUMMARY OF THE STUDY}

Foreign students make up an important percentage of the student population on campuses of institutions of higher education in Oregon. These students may be enrolled as either undergraduate students, graduate students or students in the English as a second language program at a particular institution. Statistics on numbers of foreign students in the five institutions participating in this study appear in Appendix B.

Enrollment management as a planning method for domestic students is relatively new and according to the literature, foreign students have not yet been specifically designated within this method. This study addresses the presence of foreign students at 
institutions of higher education, and three institutional units that work closely with foreign students at an institution.

The focus of the study centers around the following basic questions related to enrollment planning and institutional coordination for foreign students from the point of view of the three units described in this study.

1. According to admissions directors, what are the institutional enrollment management objectives, both domestic and foreign, and how are foreign student objectives carried out and coordinated throughout the campus?

2. According to the international student services officer, what is the role of international student services in foreign student enrollment planning institutionally and within their own unit?

3. According to the English language program director, how does the English as a second language program manage ESL enrollment and how do they coordinate through the campus?

To obtain data in response to those guiding questions, interviews were conducted at five institutions of higher education in Oregon. Three were public institutions and two were private institutions.

In general, there was evidence in the literature of a lack of institutional planning policy for foreign students and that foreign students would continue to study in the US and thus the need for creation of principles to support their enrollment and stay in the US. I undertook this study specific to schools in Oregon to determine 
whether this evidence was true of institutions in this state based on interviews with the three unit officers described in this study. These officers may or may not be players in the actual policy making, but as implementers of policy, they provide a source of information which has the possibility of revealing what kind of policy is implemented, thus possibly showing what kind of policy exists in individual institutions.

\section{CONCLUSIONS: ADMISSIONS DIRECTORS}

In regards to the status of admissions director concerns over foreign students, the findings indicate a slight increase in the action of admission directors toward foreign student enrollment planning. This is a positive sign because it means that directors are beginning to think about foreign students in relation to institutional enrollment planning.

The results of data collection with admissions directors support Hossler's (1985) claim that although trends in student population are requiring increased activity in the areas of marketing and recruitment, these efforts "have often lacked a systematic and integrated approach to the management of enrollments" (p. 26). The OSSHE Board's proposal for a systemwide enrollment management plan is a positive example of effort to develop an integrated approach to enrollment management.

From the Board's plan, each institution will be able to design a plan to meet its individual needs. In order to realize institutional 
missions, impetus from the Board and in turn, university presidents who serve on the Board, will provide a unifying support for changes in individual institutions. This is consistent with Kemerer's (198485) view that departments act as units who need to reorganize their individual missions and goals in terms of enrollment and then work together with the top administrators in order to achieve these goals.

Designing institutional missions also will aid institutions in determining their foreign student policy because established guidelines reflect, in part at least, the philosophy of the individual institutions in supporting a foreign student program (Elliot 1969).

\section{CONCLUSIONS: INTERNATIONAL STUDENT SERVICES OFFICERS}

The second focus of this study was to interview ISS officers as to the state of enrollment planning for foreign students including preparation of services and so on. One finding from several ISS officers is their concern over the low institutional priority given to foreign students. They indicated that the lack of priority their issues and clients receive reinforces the difficulty in serving foreign students without institutional support. This sentiment is echoed in Rogers' (1984) observation that "the absence of an explicit institutional foreign-student policy is perhaps most keenly felt at the operational level by staff who share responsibility for implementing an institution's foreign-student program" (p. 22).

There is evidence of cooperation between ISS and admissions and ESL which facilitates each unit in carrying out departmental 
responsibilities. Yet, the individuals who complimented the coordination also said it was due to the players. Several ISS officers were relatively content with certain areas within the system where strong coordination had developed. Still, when questioned, many seemed to feel there could be improvements in the way the institution as a whole views foreign students. I recommend that ISS officers from the different institutions work together to bring before the OSSHE board a proposal to make foreign students a higher institutional priority in the State System and in individual institutions.

\section{CONCLUSIONS: ENGLISH AS A SECOND LANGUAGE PROGRAM DIRECTORS}

ESL directors do run successful programs and do have mechanisms in place for managing ESL student enrollment, but it was not revealed through interviews that that there was a systematic plan in place. I recommend that ESL directors not only aim to design a plan, but to also enlist the aid of individuals trained in enrollment management to carry out this process. In defining one's policy or plan, the process helps to understand one's reasons and motivations. This understanding can help to improve programs for staff and students. That, coupled with practical training in enrollment management could help ESL directors to better anticipate and plan for foreign students enrolling in their programs. 
Further still, in developing a system, experienced practitioners may learn from the process "why some enrollment management practices that they do intuitively are so successful" (Hossler and Bean 1990, p. xv). With a system in place, administrators can judge whether the steps presently taken are appropriately bringing them toward their goals.

\section{GENERAL CONCLUSIONS}

The unique nature, of each institution requires that a different approach be taken toward enrollment management and foreign student policy. This is because "every successful enrollment management system reflects the unique characteristics of a campus and the administrative staff who work at the institution" (Hossler and Bean 1990, p. 1). The private schools seem to already have a more detailed process in place and in many cases, more staff per number of students which helps to increase efficiency. The public institutions in many cases seem to be in need of more support staff to improve service for foreign students in all three units interviewed.

As stated in the beginning of this paper, an enrollment plan may adapt one of the four models for an enrollment management system as described by Hossler and Bean (1990) which include the enrollment management committee, the enrollment management coordinator, the enrollment management matrix, or the enrollment management division. Furthermore, whichever framework is 
adopted or used, there are certain areas of a campus system that should be overseen by the head, or heads of an enrollment management program. Again, these areas include, student marketing and recruitment, pricing and career advising, academic assistance programs, institutional research, orientation retention programs, institutional research, orientation, retention programs, and student services (Hossler 1985). Also, as a part of this list should be units responsible for foreign students on campus which include the international services unit and the English as a second language program unit.

The initial stage of beginning an enrollment management system which includes foreign students could begin with the following steps. The first is to decide which of the models an institution is best suited to follow. If the institution is in a crisis situation and in need of a high degree of restructuring it may turn to the matrix model or division model which is supported by top senior-level administrators. If an institution is interested in starting to look at enrollment management issues, the committee model or the manager model may be a comfortable, adaptable framework. However, as these last two models do not require support from top administrators, they have the potential to be less effective than the other two models. For example, if once they are initiated they do not expand and grow within the institution, their power base may remain relatively weak without administrative support. 
Foreign students can be considered along with domestic students when planning takes place in any one of these models. Consideration of foreign students also includes recognition of the NAFSA standards discussed earlier in this paper or adherence to an institution's previously developed guidelines for working with foreign students.

\section{LIMITATIONS}

This study was conducted within the state of Oregon the results and conclusions may not be applicable to other institutions of higher education in other states. Furthermore, the five institutions participating in this study represent a very broad range of institutions of higher education in the state; therefore, the results provide a small sample of a variety of institutions rather than extensive data on one particular type of college or university.

The type of policy analysis in this paper is less rigorous than that of policy planning disciplines. This difference should be kept in mind upon review of this study so that the reader is guided by the design of this paper and not by the prescribed form and style of other disciplines. 


\section{RECOMMENDATIONS FOR FURTHER ACTION}

Some common themes emerged as a result of data gathered in the fifteen interviews with university and college administrators and can serve as recommendations.

The first is that individual units may benefit from formally defining their departmental mission. This can serve two purposes. One is to engage in this process to learn what the unit's goals are, to determine if all members within a unit are in agreement and to verify whether goals have changed from previous years. The second purpose in defining goals is to be prepared to state departmental goals when the entire institution defines its mission because an institutional mission will be the product of the various units within it.

The second recommendation is that institutions define their missions regarding foreign students. By doing this, they begin to build a framework in which to determine policy. If the mission is institutionally designed, policy created within the framework should then aim to be consistent with the goals of individuals units. An example of this would be the case where an ISS unit's goal is to have a ratio of 350 foreign students to one foreign student adviser and the university president decides there needs to be an increase of foreign students to $10 \%$ of the student body. If institutional policy aims to be consistent with unit goals, then the president would not ask admissions to implement this without including ISS in preliminary discussions. 
Related to this type of consistency is the third recommendation, which is to formally coordinate with units across campus to serve the foreign student so that success is not just a reflection of players, but is due to the internal strength of a structure. Hossler (1985) and Kemerer (1984-85) both hold that an enrollment management system should involve the entire campus. As an example, all ISS officers said that basically other departments do not consult them on trends of foreign students for any purposeful planning, rather occasionally just out of curiosity. Consistently, business and engineering receive the highest percentage of foreign students. As one public institution indicated, coordination between ISS and these departments would facilitate the smooth transition of foreign students into these programs. Furthermore, many ESL students transition into regular programs. This could be made smoother by coordination between ESL and other departments. An example would be inviting ESL students to departmental open houses, in order to help them feel a part of the total campus environment. It is all a question of the responsibility to serve students who have been welcomed onto campus.

Finally, as far as the schools within the Oregon State System of Higher Education, it may be beneficial to challenge the State Board to determine a foreign student policy for the coming years. This would indicate as a state system, how willing they are to stand behind individual institutional missions both monetarily and philosophically. 


\section{REFERENCES}

Agarwal, V., and Winkler, D. (1985). Migration of Foreign Students to the United States. Journal of Higher Education, $\underline{56}$, No. 5, 509-22.

American Council on Education. (1982). Foreign Students and Institutional Policy, Washington D.C.: American Council on Education.

Barber, E. (Ed.). (1985). Foreign Student Flows. New York: Institute of International Education.

Beeler, K. (1989). Decision Support Systems and the Art of Enrollment Management. NASPA Journal, 26, No. 4, 242-247.

Cieslak, E. (1955). The Foreign Student in American Colleges. Detroit: Wayne University Press, 1955.

Education and World Affairs. Study Committee on Foreign Student Affairs. (1964). The Foreign Student: Whom Should We Welcome?, New York: Education and World Affairs.

Elliot, G. (1969). The Dilemma of Foreign Student Admissions. Junior College Journal, 17-20.

Hossler, D. (1985). Managing Enrollments for Institutional Vitality. The College Board Review, No. 137, 26-29.

Hossler, D., Bean, J. (Eds.). (1990). The Strategic Management of College Enrollments. San Francisco: Jossey-Bass Inc., Publishers, 1990.

Hossler, D., \& Kemerer, F. (1986). Enrollment Management and Its Context. New Directions for Higher Education, No. 53, 5-14. 
Kaplan, R. (1987). Foreign Students: Developing Institutional Policy. The College Board Review, No. 143, 7-9, 28-30.

Kemerer, F. (1984-85). The Role of Deans, Department Chairs, and Faculty in Enrollment Management. The College Board Review, No. 134, 6-8, 28-29.

Kemerer, F., Baldridge, J., \& Green, K. (1982). The Enrollment Crisis: Factors, Actors and Impacts. AAHE-ERIC/Higher Education Research Report No. 3, 1982. Washington D.C., American Association for Higher Education..

Mead, L., \& Davidson, J. (1986a). Forecasting Enrollment in Intensive English Language Programs. Paper presented at the Annual Meeting of TESOL, Anaheim, CA, March 3-8.

Mead, L., \& Davidson, J. (1986b). Forecasting Enrollment in Intensive English Language Programs. TESOL Quarterly, 20, No. 3, 14, 16.

Merante, J., (1987). Organizing to Manage Enrollment. The College Board Review, No. 145, 15-17, 31-33.

Open Doors. New York: Institute of International Education, (198889 and 1990-91).

Oregon State System of Higher Education. Board Minutes (1988$1991)$.

Oregon State System of Higher Education. Strategic Plan (19871993 ).

Quann, J., (Ed.). (1979). Admissions, Academic Records, and Registrar Services. San Francisco: Jossey-Bass, Inc., Publishers.

Rogers, K. (1984). Foreign Students Economic Benefit or Liability? The College Board Review, No. 133, 20-25.

Slocum, J. (1984). Trends and Prospects in Foreign Student Admissions. The College Board Review, No. 132, 23-25, 33. 
APPENDIX A

\section{INTERVIEW QUESTIONS}


Questions of Admissions Directors

1. What are this institution's objectives for enrollment management?

2. Who at your institution is involved in enrollment management?

3. How are departments across the campus involved in enrollment management?

4. What are the skills necessary for the Director of Admissions to effectively manage enrollments?

\section{Questions of Admissions Directors regarding foreign students}

5. What is your policy for admission of foreign students?

6. Who is involved in foreign student admission?

7. Do you try to balance the number of foreign students by maintaining a diverse foreign student population?

8. Do you keep record of changes in foreign student enrollment?

9. Have there been any changes in the way you plan for enrollments in the past five years?

10. Have there been any drastic changes in foreign student enrollment due to world events. How have you responded to them?

11. Has there been any enrollment crisis which has caused you to reevaluate your current system of enrollment management?

12. What procedure do those students follow who apply to the institution, but who do not have the required English proficiency level?

13. How is enrollment management handled in the intensive English language program on your campus? 
Questions to International Student Services

1. Do you play a part in enrollment planning for foreign students on this campus?

2. Do you work with any other departments on campus regarding enrollment of foreign students?

3. Are you ever consulted by other departments for trends or migration patterns of foreign students?

4. Does your office consult with the English as a second language program on your campus in determining foreign student needs at your institution?

5. Is your office in contact with other international student organizations such as the Institute of International Education which are concerned with studying foreign student flows?

6. Foreign students who are enrolled in the university come to you for the services you provide. How do you plan for those services? Do you react to the degree of need after the students are here? Do you anticipate needs based on the previous year(s)?

7. Do you engage in any kind of trend analysis whereby you watch the enrollment trends by certain countries or kinds of foreign students and make predictions based on this for your own use in structuring your office or the services you provide?

Questions to the Director of the English Language Program 1a. Do you have a system of enrollment management for your program?

2a. Who is responsible for responding to enrollment concerns for the ESL program?

b. How has this person been trained for this aspect of his/her position?

3. Is there any coordination between your ESL program and the admissions office (or other offices on campus) with respect to enrollment planning? 
4. Are you asked by higher governing departments to forecast ESL student enrollment for budgetary purposes?

5. Does your program have a maximum number of students that it will accept in any given term?

6. Do you actively seek to maintain a balance of students by country of origin through recruitment?

7. Does your department (or institution) watch the economic and political relationships among countries to predict student flows?

8. What happens if there is a dramatic shift in enrollment either up or down? 


\section{APPENDIX B}

\section{OREGON ENROLLMENT STATISTICS}




\begin{tabular}{|c|c|c|c|c|c|c|c|}
\hline & $\begin{array}{l}\text { Total } \\
1989 \\
\end{array}$ & $\begin{array}{c}\text { ollment* } \\
1990 \\
\end{array}$ & $\begin{array}{l}\text { Forei } \\
89 / 90 \\
\end{array}$ & $\begin{array}{l}\text { gn** } \\
90 / 91\end{array}$ & & $\begin{array}{l}\text { ESL* } \\
89 / 90 \\
\end{array}$ & $90 / 91$ \\
\hline UO & 17,688 & 18,530 & 1,435 & 1,278 & & 172 & 177 \\
\hline PSU & 14,404 & 16,021 & 740 & 809 & & 91 & 110 \\
\hline OSU & 15,199 & 15,637 & 1,817 & 1,534 & & 180 & 163 \\
\hline $\begin{array}{l}\text { Lewis \& } \\
\text { Clark }\end{array}$ & 2,956 & 3,197 & 244 & 240 & & 103 & 99 \\
\hline Linfield & 1,501 & $1,501 * * *$ & $83(E)$ & 69 & & 30 & 24 \\
\hline $\begin{array}{ll}* & \text { Source: } \\
* * & \text { Source: } \\
* * * \quad \text { Duplic } \\
(\mathrm{E})= & \text { estima }\end{array}$ & \multicolumn{7}{|c|}{$\begin{array}{l}\text { HEP Higher Education Directory (1989 and 1990) } \\
\text { Open Doors (1990-1991) issue. } \\
\text { cation not an error on the part of this author } \\
\text { ate }\end{array}$} \\
\hline
\end{tabular}

